OPEN ACCESS

Edited by:

Rene Duquesnoy,

University of Pittsburgh, USA

Reviewed by:

Eric Spierings,

Utrecht University, Netherlands

Judy Day,

University of Tennessee, USA

${ }^{*}$ Correspondence:

Julia C. Arciero

jarciero@iupui.edu;

Giorgio Raimondi

g.raimondi@jhmi.edu

Specialty section:

This article was submitted to Alloimmunity and Transplantation,

a section of the

journal Frontiers in Immunology

Received: 02 May 2016

Accepted: 10 October 2016

Published: 07 November 2016

Citation:

Arciero JC, Maturo A, Arun A, Oh BC, Brandacher G and Raimondi G (2016)

Combining Theoretical and Experimental Techniques to Study Murine Heart Transplant Rejection. Front. Immunol. 7:448.

doi: 10.3389/fimmu.2016.00448

\section{Combining Theoretical and Experimental Techniques to Study Murine Heart Transplant Rejection}

\author{
Julia C. Arciero ${ }^{1 *}$, Andrew Maturo ${ }^{1}$, Anirudh Arun ${ }^{2}$, Byoung Chol $\mathrm{Oh}^{2}$, Gerald Brandacher ${ }^{2}$ \\ and Giorgio Raimondi ${ }^{2 *}$

\footnotetext{
${ }^{1}$ Department of Mathematical Sciences, Indiana University-Purdue University Indianapolis, Indianapolis, IN, USA,
} \\ ${ }^{2}$ Vascularized and Composite Allotransplantation Laboratory, Department of Plastic and Reconstructive Surgery, \\ Johns Hopkins School of Medicine, Baltimore, MD, USA
}

The quality of life of organ transplant recipients is compromised by complications associated with life-long immunosuppression, such as hypertension, diabetes, opportunistic infections, and cancer. Moreover, the absence of established tolerance to the transplanted tissues causes limited long-term graft survival rates. Thus, there is a great medical need to understand the complex immune system interactions that lead to transplant rejection so that novel and effective strategies of intervention that redirect the system toward transplant acceptance (while preserving overall immune competence) can be identified. This study implements a systems biology approach in which an experimentally based mathematical model is used to predict how alterations in the immune response influence the rejection of mouse heart transplants. Five stages of conventional mouse heart transplantation are modeled using a system of 13 ordinary differential equations that tracks populations of both innate and adaptive immunity as well as proxies for pro- and anti-inflammatory factors within the graft and a representative draining lymph node. The model correctly reproduces known experimental outcomes, such as indefinite survival of the graft in the absence of $\mathrm{CD} 4^{+} \mathrm{T}$ cells and quick rejection in the absence of $\mathrm{CD}^{+}+\mathrm{T}$ cells. The model predicts that decreasing the translocation rate of effector cells from the lymph node to the graft delays transplant rejection. Increasing the starting number of quiescent regulatory $T$ cells in the model yields a significant but somewhat limited protective effect on graft survival. Surprisingly, the model shows that a delayed appearance of alloreactive $T$ cells has an impact on graft survival that does not correlate linearly with the time delay. This computational model represents one of the first comprehensive approaches toward simulating the many interacting components of the immune system. Despite some limitations, the model provides important suggestions of experimental investigations that could improve the understanding of rejection. Overall, the systems biology approach used here is a first step in predicting treatments and interventions that can induce transplant tolerance while preserving the capacity of the immune system to protect against legitimate pathogens.

Keywords: mathematical model, transplant, rejection, immune response, antigen-presenting cells, T cells, cytokines

Abbreviations: APCs, antigen-presenting cells; POD, post-operative day; Treg, regulatory T cells. 


\section{INTRODUCTION}

Organ transplantation is a life-saving surgical procedure through which the functionality of a failing organ can be restored via replacement with a functioning one. Transplants are performed for a wide variety of organs, including skin, heart, kidney, liver, pancreas, spleen, and lung (1). However, without the administration of immunosuppressive drugs, the recipient's immune system recognizes the transplanted tissue as a foreign and potentially dangerous material and responds with a massive immune attack that ultimately destroys the graft. This immune response represents a major roadblock in the development of effective therapeutic regimens for the care of patients requiring organ transplants. Current therapeutic regimens rely on chronic immunosuppression. However, the quality of life of transplant recipients is compromised by complications that derive from life-long immunosuppression (such as hypertension, diabetes, opportunistic infections, and cancer) and by the limited long-term graft survival rates due to the absence of established immune tolerance to the transplanted tissues. Ultimately, $20 \%$ or more of transplanted patients die by 5 years post-transplant. Thus, there is a pressing need for a new investigative approach to understand the systemic effects that arise from the dynamic interactions between components of the immune system and transplanted tissues.

Previous hypothesis-driven research has provided important insight into the complex interactions among the multiple components of the immune system, including $\mathrm{T}$ cells, antigen-presenting cells (APCs), and cytokines (2-10). Such studies have helped to determine the critical players and processes in transplant rejection. For example, the rationale for "costimulation blockade" therapies stems from such studies. These therapies, which target a key step of lymphocyte activation, aim to control T cell activation and promote transplant survival. They have been shown to be a potent strategy for promoting long-term acceptance of transplants in rodents (11-15) and primates (16-18). However, their clinical translation encountered serious difficulties, and ultimately costimulation blockade therapies were only approved as maintenance therapies (19) since they could not promote tolerance (20). To date, the only clinically successful avenue of transplant tolerance induction has been through protocols that induce hematopoietic chimerism $(21,22)$ (the coexistence of donor and recipient hematopoietic cells) via donor bone marrow co-transplantation with the organ to be transferred. This procedure requires heavy conditioning of patients and carries a significant risk of immunological complications (e.g., the development of graft versus host disease). Consequently, this approach is applicable only in a very restricted cohort of patients in need of a transplant. Thus, a valid and widely applicable strategy to alter the reactivity of the immune system of transplant recipients in a robust and reliable way is still needed.

Biological studies of rejection face various challenges. Experimental in vivo models of immune rejection can elucidate precise information regarding select immune cell dynamics and the production and distribution of cytokines. However, conclusions about the system as a whole and the generalizability of these conclusions to other species or types of allografts are further complicated by factors such as procedural variability between models of rejection and variability in parameter measurements. These factors, in combination with the complexity of the immune response, motivate the use of an integrated theoretical and experimental approach to unravel the inter-connected components of the immune response that contribute to transplant rejection. A mathematical model of allograft rejection, refined by multiple clinical and experimental observations, can help to identify variables and parameters that play a significant role in immune system dynamics and yield a better understanding of the complex mechanisms of transplant rejection.

Several computational models have been implemented to predict the dynamics of the immune system in response to viral or bacterial infections (23-26), although only a few theoretical studies have addressed transplant rejection. A recent publication used agent-based modeling (ABM) to investigate solid organ transplant rejection (27). In their study, the model provides an abstract representation of the innate and adaptive immune components involved in the acute rejection process of a solid organ transplant. The study does not use experimentally based parameter values, but it gives a range of possible responses to a transplant challenge without replicating a specific disease process. Another recent study (28) used ordinary differential equations to model the impact of the initial inflammatory response to a surgical insult on overall graft damage. These studies have addressed general transplant immunology questions and have studied a very specific aspect of the initiation of the transplant rejection response, but they do not offer the capacity to capture the important intricacies of the rejection response in a combined experimental and theoretical system that could lead to useful predictions to design new experimentations. The mathematical model presented in the current study aims to provide useful theoretical predictions of transplant rejection based on biologically relevant parameter values, initial conditions, and cellular interactions.

The objectives of this study are (i) to develop a theoretical model to predict the effect of the immune response dynamics on the rejection of a murine heart transplant based on experimental measurements, and (ii) to identify new and effective strategies to promote transplant acceptance that could be investigated experimentally. The model is composed of a system of ordinary differential equations describing the cellular dynamics in the lymph node and graft in the context of a simulated acute rejection of murine heart allograft. The model equations and parameters are based on previous immune system models and are designed to incorporate key assumptions and experimental observations of the immune response to murine heart transplants. The model captures the known behavior of mouse heart rejection and recapitulates the effect of previously reported experimental manipulations. It also underscores the relative importance of the ratios of effector versus regulatory $\mathrm{T}$ cells (Tregs) on the speed of graft rejection. Importantly, the model predicts a previously unappreciated behavior when altering the timing of $\mathrm{T}$ cell exposure to the graft, providing details for the design of new experimentations that could confirm or refute these findings. Ultimately, we believe this model could become an innovative tool to improve our understanding of transplant rejection and significantly aid in the design of new and effective strategies of immune intervention. 


\section{MATERIALS AND METHODS}

\section{Model Development}

In this study, a mathematical model of murine heart transplants is developed to investigate the interactions between the host immune system and transplanted graft. A compartmental model is used in which all interactions are assumed to occur in either the graft or the draining lymph node. A separate compartment for blood is not included, but the rates of exit and entry of the various cells into the graft or lymph node are assumed to account for transit time in the blood. Table 1 provides the definition and description of all the variables tracked by this model. As with any model, some assumptions and simplifications are necessary to address a specific question using quantitative techniques.

The following list provides a summary of the assumptions made in this study:

- Antigen-presenting cells: a single population of APCs is defined in the model and includes the populations of dendritic cells, macrophages, and B cells; no distinction is made between the origin of the APCs (donor or recipient);

- Antigen presentation: direct, indirect, and semi-direct antigen presentation pathways are grouped into a single function;

- Rejection mechanisms: only cell-mediated mechanisms of graft cell destruction (by effector T cells and inflammatory APCs) are included since the absence of B cells and associated antibody production in mouse heart transplant models (obtained via genetic manipulation or depletion strategies) does not extend graft survival (29);

- Lymphoid tissue: the activation of the immune response is restricted to an ideal lymph node that drains the graft. The contribution of the response by multiple lymphoid tissues is accounted for by amplifying the translocation rate of activated $\mathrm{T}$ cells from a single lymph node to the graft;

- Naïve T cells: the population of graft-reactive T cells is considered to be homogeneously naïve. No contribution of memory $\mathrm{T}$ cells is considered at this stage. A continuous output of newly generated $\mathrm{T}$ cells (from the thymus) is assumed to maintain a constant number of naive T cells in the lymph node. Of the total $\mathrm{T}$ cell population, $5 \%$ are considered to be alloreactive (30);

TABLE 1 | Description of model variables.

\begin{tabular}{lll}
\hline Variable & Description & Location \\
\hline$A_{m a t}^{L N}$ & Mature antigen-presenting cells & Lymph node \\
$T_{E}^{L N}$ & Activated effector T cells & \\
$T_{R}^{L N}$ & Activated regulatory T cells & \\
$T_{H}^{L N}$ & Activated helper T cells & Graft \\
$A_{m a t}^{G}$ & Mature antigen-presenting cells & \\
$A_{i m m}^{G}$ & Immature antigen-presenting cells & \\
$A_{i n f}^{G}$ & Inflammatory antigen-presenting cells \\
$T_{E}^{G}$ & Activated effector T cells & \\
$T_{R}^{G}$ & Activated regulatory T cells & \\
$T_{H}^{G}$ & Activated helper T cells & \\
$G^{G}$ & Graft cells & \\
$C_{p}^{G}$ & Pro-inflammatory cytokine & \\
$C_{a}^{G}$ & Anti-inflammatory cytokine &
\end{tabular}

- Inflammatory response: the danger signals generated by the surgical procedure of transplantation (e.g., surgical trauma, ischemia/reperfusion injury, and potential exposure to bacterial and viral components) (31) and the ensuing release of inflammatory cytokines (i.e., IL-6, IL-18, TNF, IP-10, IL-1) by graft tissues and innate immune components are simplified and represented in a single population $\left(\mathrm{C}_{\mathrm{p}}^{\mathrm{G}}\right)$. No contribution to the rejection response by concomitant protective immune responses (anti-pathogens) is assumed. Moreover, as no specific quantification of each of inflammatory factors is currently available in the literature, their functions and behavior are represented with a single model variable. $C_{p}^{G}$ has both inflammatory and chemotactic functions, and its behavior is initially modeled based on the production and accumulation of IL-6, the most representative inflammatory cytokine in transplantation as previously reported $(32,33)$;

- Anti-inflammatory response: the anti-inflammatory cytokines (i.e., IL-10, TGF- $\beta$, IL-35, pro-resolving mediators) normally produced by graft tissues and cells of the immune system as compensatory mechanisms to the inflammatory response initiated by the transplant and by the rejection response are all included in a single population $\left(\mathrm{C}_{\mathrm{a}}^{\mathrm{G}}\right)$. As per $\mathrm{C}_{\mathrm{p}}^{\mathrm{G}}$, there is no transplant-specific quantification available for these factors and $\mathrm{C}_{\mathrm{a}}^{\mathrm{G}}$ is mainly modeled on the behavior reported for IL-10 in the regulation of immune responses (34-36).

- Graft cells turnover: the growth of heart cells is considered negligible in the model based on reported data (37).

With these assumptions, the dynamics between the immune system and the graft are described in the following five stages (and are depicted in Figure 1):

1. Transplantation: transplantation (introduction of the graft) occurs at day 0 and is captured by the model using the following initial conditions (listed in Table 2) for the graft population $\left(\mathrm{G}^{\mathrm{G}}\right)$, pro-inflammatory cytokines $\left(\mathrm{C}_{\mathrm{p}}^{\mathrm{G}}\right)$, and immature APCs $\left(\mathrm{A}_{\mathrm{imm}}^{\mathrm{G}}\right): \mathrm{G}^{\mathrm{G}}(0)=5,600,000$ cells $(38,39), \mathrm{C}_{\mathrm{p}}^{\mathrm{G}}(0)=50 \mathrm{pg} / \mathrm{ml}$ $(32,33)$, and $A_{i m m}^{G}=2,000$ cells $(40,41) \cdot G^{G}(0)$ was chosen by extrapolating the number of cells in a mouse heart based on the average mass of a mouse heart and the average cell density of a human heart. Pro-inflammatory cytokines are assumed to be present at time 0 since transplantation is associated with surgical trauma and exposure to bacterial and viral agents. Additionally, during the procedure, the reconnection to the recipient circulation initiates the process of ischemia/reperfusion injury, causing rapid accumulation of inflammatory mediators $(31,42,43)$. Although there is a general agreement on the presence of inflammatory elements at time 0 , the overall amount is not known and, thus, an arbitrary value is chosen here. This value reflects the kinetics of mRNA expression and plasma accumulation of IL-6 - a key "danger signal" in the activation of the immune system in transplantation - that have been described previously $(32,33)$. The presence of these inflammatory cytokines leads to a rapid influx of host immature APCs into the graft (representing the influx of circulating monocytes rapidly converting in the tissues into APCs). 


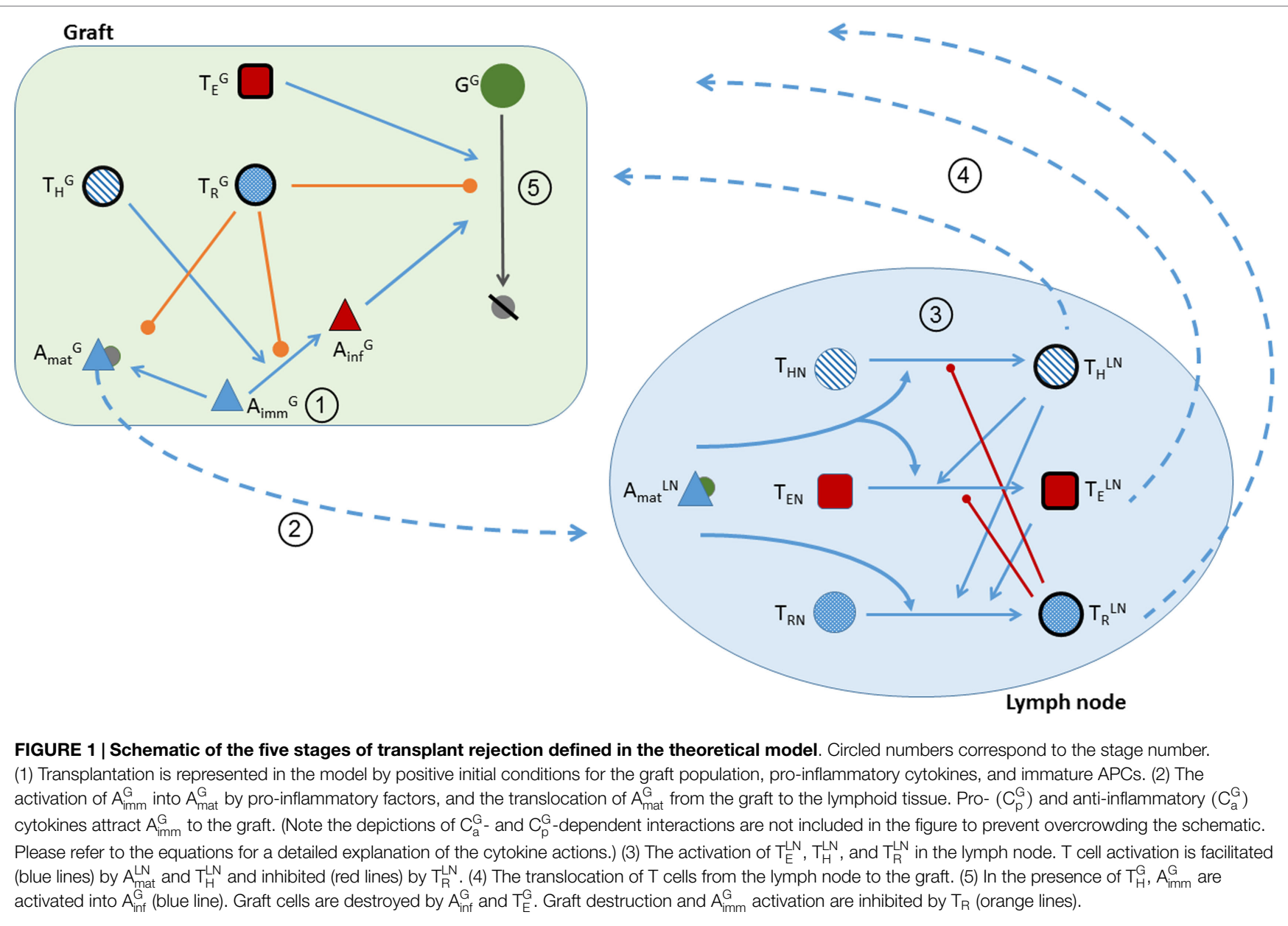

TABLE 2 | Initial values for model variables.

\begin{tabular}{lcl}
\hline Variable & Initial value & Unit \\
\hline$A_{m a t}^{L N}$ & 0 & cells \\
$T_{E}^{L N}$ & 0 & cells \\
$T_{R}^{L N}$ & 0 & cells \\
$T_{H}^{L N}$ & 0 & cells \\
$A_{m a t}^{G}$ & 200 & cells \\
$A_{\text {imm }}^{G}$ & 2,000 & cells \\
$A_{\text {inf }}^{G}$ & 0 & cells \\
$T_{E}^{G}$ & 0 & cells \\
$T_{R}^{G}$ & 0 & cells \\
$T_{H}^{G}$ & 0 & cells \\
$G^{G}$ & $5.6 e 6$ & cells \\
$C_{p}^{G}$ & 50 & $\mathrm{pg} / \mathrm{ml}$ \\
$C_{a}^{G}$ & 0 & $\mathrm{pg} / \mathrm{ml}$
\end{tabular}

2. APC maturation and presentation of donor antigens in the lymph node: once exposed to $\mathrm{C}_{\mathrm{p}}^{\mathrm{G}}$, immature APCs are activated into mature APCs in the graft $\left(\mathrm{A}_{\text {mat }}^{\mathrm{G}}\right)$. The maturation of APCs contributes to an increased accumulation of pro-inflammatory factors as well as, in a delayed fashion, to the production of anti-inflammatory factors $\left(\mathrm{C}_{\mathrm{a}}^{\mathrm{G}}\right)(34-36)$. Once mature, APCs exit the graft and travel to the draining lymphoid tissue.
3. Activation of $T$ cells in the lymph node: in the theoretical model of the lymph node, naive $\mathrm{CD} 8^{+}$effector $\mathrm{T}$ cells $\left(\mathrm{T}_{\mathrm{EN}}\right)$, naïve Tregs $\left(\mathrm{T}_{\mathrm{RN}}\right)$, and naïve $\mathrm{CD} 4^{+}$helper $\mathrm{T}$ cells $\left(\mathrm{T}_{\mathrm{HN}}\right)$ that have the capacity to recognize donor antigens are assumed to be present initially at background levels of 55,000, 9,500, and 70,000 cells, respectively. Upon entering the lymph node, $A_{\text {mat }}^{\mathrm{LN}}$ facilitate the activation of T cells $(6,10)$. As shown in Figure 1, $\mathrm{A}_{\text {mat }}^{\mathrm{LN}}$ are necessary to promote the activation of naive $\mathrm{CD} 8^{+}$ $\left(\mathrm{T}_{\mathrm{E}}^{\mathrm{LN}}\right), \mathrm{CD}^{+}\left(\mathrm{T}_{\mathrm{H}}^{\mathrm{LN}}\right)$, and regulatory $\left(\mathrm{T}_{\mathrm{R}}^{\mathrm{LN}}\right) \mathrm{T}$ cells in the lymph node. $\mathrm{CD}^{+} \mathrm{T}$ cell activation is dependent on the licensing of interacting APCs by activated $\mathrm{CD} 4^{+} \mathrm{T}$ cells. Once activated, Tregs inhibit the activation of $\mathrm{CD} 8^{+}$and $\mathrm{CD} 4^{+} \mathrm{T}$ cells. T cell proliferation in the lymph node depends on the autocrine and paracrine effects of growth factors (e.g., IL-2). Tregs are unable to produce and secrete these growth factors and, thus, their proliferation is delayed and dependent on the presence of activated $\mathrm{CD} 4^{+}$and $\mathrm{CD} 8^{+} \mathrm{T}$ cells (44).

4. $T$ cell infiltration of the graft: following their activation, $\mathrm{T}_{\mathrm{E}}^{\mathrm{LN}}$, $\mathrm{T}_{\mathrm{H}}^{\mathrm{LN}}$, and $\mathrm{T}_{\mathrm{R}}^{\mathrm{LN}}$ exit the lymph node and search for the inflamed tissues of the graft. It is important to note that not all $\mathrm{T}$ cells exiting the lymph node will locate the graft. Also, though T cells originate from multiple lymph nodes, only one lymph node is explicitly depicted and described in the model for simplicity. The translocation rate parameters $e_{E}, e_{H}$, and $e_{R}$ in Eqs 8-10 are multiplied by a factor $k$ that accounts for the contribution 
of these two phenomena to the number of cells entering the graft. Specifically, the parameter $\mathrm{k}$ is interpreted as the product of the percent of $\mathrm{T}$ cells that reach the graft and the number of lymph nodes (and spleen) from which $\mathrm{T}$ cells originate.

5. Destruction of the graft: in the graft, $\mathrm{T}_{\mathrm{H}}^{\mathrm{G}}$ promote the conversion of $\mathrm{A}_{\mathrm{imm}}^{\mathrm{G}}$ into inflammatory APCs $\left(\mathrm{A}_{\mathrm{inf}}^{\mathrm{G}}\right)$; this represents the activation of macrophages into inflammatory cells that release cytotoxic agents (e.g., reactive oxygen species) that induce death of surrounding graft cells. This process is inhibited by $\mathrm{T}_{\mathrm{R}}^{\mathrm{G}}(45,46)$. The release of pro-inflammatory cytokines is promoted in the presence of $A_{\text {mat }}^{G}, T_{E}^{G}, T_{H}^{G}$, and $A_{\text {inf. The }}^{G}$ release of $C_{a}^{G}$ is assumed to depend on $A_{\text {mat }}^{G}, T_{R}^{G}, C_{p}^{G}, G^{G}$, and $A_{\text {inf }}^{G}$ (47). The presence of $C_{a}^{G}$ inhibits the conversion of $A_{i m m}^{G}$ into $A_{\text {mat }}^{G}$ or $A_{\text {inf }}^{G}$. $A_{\text {inf }}^{G}$ and $T_{E}^{G}$ direct the destruction of the graft, while $\mathrm{T}_{\mathrm{R}}^{\mathrm{G}}$ inhibit graft destruction.

\section{Model Equations}

The interactions described in the five stages are modeled using a system of 13 ordinary differential equations that tracks cell populations and cytokine concentrations within the graft and lymph node. Many of the parameter values are taken directly from literature sources, some were obtained experimentally, and the remaining are estimated according to experimental assumptions and observations. The initial values of all model variables are given in Table 2. The model parameter values, units, and references are listed in Table 3.

The model equations describe the activation, proliferation, natural decay, destruction, and inhibition of the various populations when appropriate. The interactions in the lymph node are modeled using four equations, and the interactions in the graft are modeled using nine equations. The superscripts LN and G denote cell populations in the lymph node and graft, respectively.

In Eq. 1, the rate of change of mature APCs in the lymph node $\left(\mathrm{A}_{\mathrm{mat}}^{\mathrm{LN}}\right)$ is defined. This rate depends on the entrance of mature APCs from the graft at rate $e_{A}$ (first term) and on the natural decay of $\mathrm{A}_{\mathrm{mat}}^{\mathrm{LN}}$ in the lymph node (second term).

$$
\frac{\mathrm{dA}_{\mathrm{mat}}^{\mathrm{LN}}}{\mathrm{dt}}=\mathrm{e}_{\mathrm{A}} \mathrm{A}_{\mathrm{mat}}^{\mathrm{G}}-\mu_{\mathrm{A}} \mathrm{A}_{\mathrm{mat}}^{\mathrm{LN}}
$$

The naïve alloreactive $\mathrm{T}$ cell populations $\left(\mathrm{T}_{\mathrm{EN}}, \mathrm{T}_{\mathrm{RN}}\right.$, and $\left.\mathrm{T}_{\mathrm{HN}}\right)$ in the lymph node are assumed to be constant since a background population of these cells is always present (due to thymopoiesis).

In Eq. 2, the rate of change in $\mathrm{CD}^{+} \mathrm{T}$ cells in the lymph node is shown to depend on T cell activation (term 1), decay (term 2), proliferation (term 3 ), and translocation (term 4). The activation of $\mathrm{T}_{\mathrm{E}}^{\mathrm{LN}}$ depends on the presence of both $\mathrm{A}_{\text {mat }}^{\mathrm{LN}}$ and $\mathrm{T}_{\mathrm{H}}^{\mathrm{LN}}$, while $\mathrm{T}_{\mathrm{R}}^{\mathrm{LN}}$ inhibit this process $(10,46,51)$. Proliferation of the $\mathrm{T}_{\mathrm{E}}^{\mathrm{LN}}$ cells depends on $\mathrm{A}_{\mathrm{mat}}^{\mathrm{LN}}$ and $\mathrm{T}_{\mathrm{E}}^{\mathrm{LN}}$ and occurs at rate $\mathrm{r}_{\mathrm{E}}$ (used as a proxy for the production, secretion, and autocrine effect of IL-2) (52). The translocation of $\mathrm{T}_{\mathrm{E}}^{\mathrm{LN}}$ from the lymph node is assumed to occur at rate $\mathrm{e}_{\mathrm{E}}$.

$$
\begin{aligned}
\frac{\mathrm{dT}_{\mathrm{E}}^{\mathrm{LN}}}{\mathrm{dt}}= & \frac{\mathrm{a}_{\mathrm{E}} \mathrm{T}_{\mathrm{EN}} \mathrm{A}_{\mathrm{mat}}^{\mathrm{LN}} \mathrm{T}_{\mathrm{H}}^{\mathrm{LN}}}{\left(\gamma_{1}+\mathrm{A}_{\mathrm{mat}}^{\mathrm{LN}}\right)\left(\alpha_{1}+\mathrm{T}_{\mathrm{R}}^{\mathrm{LN}}\right)}-\mu_{\mathrm{E}} \mathrm{T}_{\mathrm{E}}^{\mathrm{LN}} \\
& +\frac{\mathrm{r}_{\mathrm{E}} \mathrm{T}_{\mathrm{E}}^{\mathrm{LN}} \mathrm{A}_{\mathrm{mat}}^{\mathrm{LN}}}{\beta_{1}+\mathrm{A}_{\mathrm{mat}}^{\mathrm{LN}}}-\mathrm{e}_{\mathrm{E}} \mathrm{T}_{\mathrm{E}}^{\mathrm{LN}}
\end{aligned}
$$

\begin{tabular}{|c|c|c|c|c|}
\hline Equation & $\begin{array}{l}\text { Parameter } \\
\text { name }\end{array}$ & Value & Unit & Source \\
\hline 1 & $\mathrm{e}_{\mathrm{A}}$ & 5.5 & 1/day & (24) \\
\hline 1 & $\mu_{\mathrm{A}}$ & 1.2 & 1/day & $(48)$ \\
\hline 2 & $\mathrm{~T}_{\mathrm{EN}}$ & 55,000 & cells & $\begin{array}{l}\text { Section "Experimental } \\
\text { Data Collection" }\end{array}$ \\
\hline 2 & $a_{E}$ & 3 & 1/day & (25) \\
\hline 2 & $\gamma_{1}$ & 100 & cells & (25) \\
\hline 2 & $\alpha_{1}$ & 2,500 & cells & Estimated \\
\hline 2 & $\mu_{\mathrm{E}}$ & 0.7 & 1/day & $(25)$ \\
\hline 2 & $r_{E}$ & 1.51 & 1/day & $(25)$ \\
\hline 2 & $\beta_{1}$ & 5,000 & cells & Estimated \\
\hline 2 & $e_{E}$ & 0.001 & 1/day & $(24)$ \\
\hline 3 & $\mathrm{~T}_{\mathrm{RN}}$ & 9,500 & cells & $\begin{array}{l}\text { Section "Experimental } \\
\text { Data Collection" }\end{array}$ \\
\hline 3 & $a_{R}$ & $2.82 e-4$ & 1/day & Optimized \\
\hline 3 & $\gamma_{2}$ & 1,000 & cells & Estimated \\
\hline 3 & $\mu_{\mathrm{R}}$ & 0.7 & 1/day & $(24,49)$ \\
\hline 3 & $r_{R}$ & 0.02 & 1/day & Estimated \\
\hline 3 & $\alpha_{2}$ & 9,500 & cells & Estimated \\
\hline 3 & $e_{R}$ & 0.001 & 1/day & $(24)$ \\
\hline 4 & $\mathrm{~T}_{\mathrm{HN}}$ & 70,000 & cells & $\begin{array}{l}\text { Section "Experimental } \\
\text { Data Collection" }\end{array}$ \\
\hline 4 & $a_{H}$ & $6,018.9$ & cells/day & Optimized \\
\hline 4 & $\gamma_{3}$ & 100 & cells & (25) \\
\hline 4 & $\alpha_{3}$ & 2,500 & cells & Estimated \\
\hline 4 & $\mu_{H}$ & 0.4 & 1/day & $(24,25)$ \\
\hline 4 & $r_{H}$ & 1.51 & 1/day & $(25,50)$ \\
\hline 4 & $\gamma_{4}$ & 4,000 & cells & (25) \\
\hline 4 & $\mathrm{e}_{\mathrm{H}}$ & 0.001 & 1/day & (24) \\
\hline 5 & $a_{p 1}$ & 1,500 & cells/day/(pg/ml) & Optimized \\
\hline 5 & $\eta_{1}$ & 10 & $\mathrm{pg} / \mathrm{ml}$ & Estimated \\
\hline 5 & $\alpha_{4}$ & 12,000 & cells & Estimated \\
\hline 6 & $\mathrm{k}_{\mathrm{C}_{\mathrm{p}}}$ & 0.005 & 1/day/(pg/ml) & Optimized \\
\hline 6 & $\mu_{\text {Aimm }}$ & 60 & 1/day & Optimized \\
\hline 6 & $a_{\mathrm{p} 2}$ & 3.844 & 1/day & Optimized \\
\hline 6 & $\eta_{2}$ & 10 & $\mathrm{pg} / \mathrm{ml}$ & Estimated \\
\hline 6 & $\alpha_{5}$ & 12,000 & cells & Estimated \\
\hline 7 & $\mu_{\text {Ainf }}$ & 1.2 & 1/day & $(48)$ \\
\hline 8 & k & 15 & - & Estimated \\
\hline 8 & $r_{E G}$ & 0.3 & 1/day & Optimized \\
\hline 8 & $\eta_{3}$ & 10 & $\mathrm{pg} / \mathrm{ml}$ & Estimated \\
\hline 8 & $\beta_{2}$ & $4 \mathrm{e} 6$ & cells & Estimated \\
\hline 9 & $r_{R G}$ & 0.00375 & 1/day & Optimized \\
\hline 9 & $\alpha_{6}$ & 12,000 & cells & Estimated \\
\hline 10 & $r_{H G}$ & 0.755 & 1/day & Estimated \\
\hline 10 & $\gamma_{5}$ & 4,000 & cells & Estimated \\
\hline 10 & $\eta_{4}$ & 10 & $\mathrm{pg} / \mathrm{ml}$ & Estimated \\
\hline 11 & $\mathrm{~d}_{\mathrm{inf}}$ & 0.055 & 1/day & Optimized \\
\hline 11 & $\alpha_{7}$ & 12,000 & cells & Estimated \\
\hline 11 & $d_{E}$ & 0.004 & cells/day & Optimized \\
\hline 11 & $\alpha_{8}$ & 12,000 & cells & Estimated \\
\hline 12 & $\rho_{1}$ & 10.98 & $(\mathrm{pg} / \mathrm{ml}) /$ day & Optimized \\
\hline 12 & $\alpha_{9}$ & 12,000 & cells & Estimated \\
\hline 12 & $\rho_{2}$ & 0.024 & $(\mathrm{pg} / \mathrm{ml}) /$ day & Estimated \\
\hline 12 & $\alpha_{10}$ & 12,000 & cells & Estimated \\
\hline 12 & $\rho_{3}$ & 0.24 & $(\mathrm{pg} / \mathrm{ml}) /$ day & Estimated \\
\hline 12 & $\alpha_{11}$ & 12,000 & cells & Estimated \\
\hline 12 & $\rho_{4}$ & 10.95 & $(\mathrm{pg} / \mathrm{ml}) / \mathrm{day}$ & Optimized \\
\hline 12 & $\alpha_{12}$ & 12,000 & cells & Estimated \\
\hline 12 & $\mu_{\mathrm{C}_{\mathrm{p}}}$ & 0.15 & 1/day & Optimized \\
\hline 13 & $\xi_{1}$ & $2.08 \mathrm{e}-4$ & $(\mathrm{pg} / \mathrm{ml}) / \mathrm{cells} /$ day & Estimated \\
\hline 13 & $\xi_{2}$ & $6.3 e-6$ & $(\mathrm{pg} / \mathrm{ml}) / \mathrm{cell} / \mathrm{day}$ & Estimated \\
\hline 13 & $\xi_{3}$ & $4.2 \mathrm{e}-9$ & 1/cells/day & Estimated \\
\hline 13 & $\xi_{4}$ & $2.5 e-4$ & $(\mathrm{pg} / \mathrm{ml}) / \mathrm{cells} /$ day & Estimated \\
\hline 13 & $\mu_{\mathrm{Ca}_{\mathrm{a}}}$ & 0.05 & 1/day & Estimated \\
\hline
\end{tabular}

TABLE 3 | Names, values, units, and citations for all model parameters. 
The rates of change of Tregs in the lymph node (Eq. 3) and $\mathrm{CD}^{+} \mathrm{T}$ cells in the lymph node (Eq. 4) contain the same four terms (activation, decay, proliferation, and exit) as the equation for $\mathrm{CD}^{+} \mathrm{T}$ cells, with a few important differences: the activation of $\mathrm{T}_{\mathrm{R}}^{\mathrm{LN}}$ and $\mathrm{T}_{\mathrm{H}}^{\mathrm{LN}}$ depends only on $\mathrm{A}_{\text {mat }}^{\mathrm{LN}}$, and the proliferation of $\mathrm{T}_{\mathrm{R}}^{\mathrm{LN}}$ occurs only in the presence of $\mathrm{T}_{\mathrm{E}}^{\mathrm{LN}}$ or $\mathrm{T}_{\mathrm{H}}^{\mathrm{LN}}$. The activation of $\mathrm{T}_{\mathrm{H}}^{\mathrm{LN}}$ is inhibited by $\mathrm{T}_{\mathrm{R}}^{\mathrm{LN}}(10,45)$.

$$
\begin{aligned}
\frac{\mathrm{dT}_{\mathrm{R}}^{\mathrm{LN}}}{\mathrm{dt}}= & \frac{\mathrm{a}_{\mathrm{R}} \mathrm{T}_{\mathrm{RN}} \mathrm{A}_{\mathrm{mat}}^{\mathrm{LN}}}{\gamma_{2}+\mathrm{A}_{\mathrm{mat}}^{\mathrm{LN}}}-\mu_{\mathrm{R}} \mathrm{T}_{\mathrm{R}}^{\mathrm{LN}}+\frac{\mathrm{r}_{\mathrm{R}} \mathrm{T}_{\mathrm{R}}^{\mathrm{LN}}\left(\mathrm{T}_{\mathrm{E}}^{\mathrm{LN}}+\mathrm{T}_{\mathrm{H}}^{\mathrm{LN}}\right)}{\alpha_{2}+\mathrm{T}_{\mathrm{R}}^{\mathrm{LN}}}-\mathrm{e}_{\mathrm{R}} \mathrm{T}_{\mathrm{R}}^{\mathrm{LN}} \\
\frac{\mathrm{dT}_{\mathrm{H}}^{\mathrm{LN}}}{\mathrm{dt}}= & \frac{\mathrm{a}_{\mathrm{H}} \mathrm{T}_{\mathrm{HN}} \mathrm{A}_{\mathrm{mat}}^{\mathrm{LN}}}{\left(\gamma_{3}+\mathrm{A}_{\mathrm{mat}}^{\mathrm{LN}}\right)\left(\alpha_{3}+\mathrm{T}_{\mathrm{R}}^{\mathrm{LN}}\right)}-\mu_{\mathrm{H}} \mathrm{T}_{\mathrm{H}}^{\mathrm{LN}} \\
& +\frac{\mathrm{r}_{\mathrm{H}} \mathrm{T}_{\mathrm{H}}^{\mathrm{LN}} \mathrm{A}_{\mathrm{mat}}^{\mathrm{LN}}}{\gamma_{4}+\mathrm{A}_{\mathrm{mat}}^{\mathrm{LN}}}-\mathrm{e}_{\mathrm{H}} \mathrm{T}_{\mathrm{H}}^{\mathrm{LN}}
\end{aligned}
$$

The rate of change of the $A_{i m m}^{G}$ population in the graft is defined in Eq. 5. The first term represents the influx of $A_{i m m}^{G}$ due to the presence of the graft and pro-inflammatory cytokines. The second term accounts for the natural decay of $\mathrm{A}_{\mathrm{imm}}^{\mathrm{G}}$. The third term indicates the loss of immature APCs once they become activated into $A_{\text {mat }}^{G}$. The fourth term defines the $T_{H}^{G}$-mediated activation of $A_{\text {imm }}^{G}$ into $A_{\text {inf. }}^{G}$ In both of these last two terms, the conversion of $A_{i m m}^{G}$ into activated populations is inhibited by $C_{a}^{G}$ and $T_{R}^{G}(35$, $47,51,53,54)$. The functional form describing the inhibition by $\mathrm{C}_{\mathrm{a}}^{\mathrm{G}}$ is chosen to emphasize that the rate is a decreasing sigmoidal function of $\mathrm{C}_{\mathrm{a}}^{\mathrm{G}}$.

$$
\begin{aligned}
\frac{\mathrm{dA}_{\mathrm{imm}}^{\mathrm{G}}}{\mathrm{dt}}= & \mathrm{k}_{\mathrm{C}_{\mathrm{p}}} \mathrm{C}_{\mathrm{p}}^{\mathrm{G}} \mathrm{G}^{\mathrm{G}}-\mu_{\text {Aimm }} \mathrm{A}_{\mathrm{imm}}^{\mathrm{G}}-\mathrm{a}_{\mathrm{p} 1}\left(1-\frac{\left(\mathrm{C}_{\mathrm{a}}^{\mathrm{G}}\right)^{2}}{\eta_{1}^{2}+\left(\mathrm{C}_{\mathrm{a}}^{\mathrm{G}}\right)^{2}}\right) \\
& \times\left(\frac{\mathrm{A}_{\mathrm{imm}}^{\mathrm{G}} \mathrm{C}_{\mathrm{p}}^{\mathrm{G}}}{\alpha_{4}+\mathrm{T}_{\mathrm{R}}^{\mathrm{G}}}\right)-\mathrm{a}_{\mathrm{p} 2}\left(1-\frac{\left(\mathrm{C}_{\mathrm{a}}^{\mathrm{G}}\right)^{2}}{\eta_{2}^{2}+\left(\mathrm{C}_{\mathrm{a}}^{\mathrm{G}}\right)^{2}}\right)\left(\frac{\mathrm{A}_{\mathrm{imm}}^{\mathrm{G}} \mathrm{T}_{\mathrm{H}}^{\mathrm{G}}}{\alpha_{5}+\mathrm{T}_{\mathrm{R}}^{\mathrm{G}}}\right)
\end{aligned}
$$

Equation 6 describes the dynamics of mature APCs in the graft $\left(A_{\text {mat }}^{G}\right)$. The first term defines the activation of $A_{\text {mat }}^{G}$ by $C_{p}^{G}$, which is inhibited by $C_{a}^{G}$ and $T_{R}^{G}(35,47,51,53,54)$. The second term is the natural decay of $\mathrm{A}_{\mathrm{mat}}^{\mathrm{G}}$, and the last term accounts for the exit of $A_{\text {mat }}^{G}$ from the graft to the lymph node.

$\frac{\mathrm{dA}_{\mathrm{mat}}^{\mathrm{G}}}{\mathrm{dt}}=\mathrm{a}_{\mathrm{p} 1}\left(1-\frac{\left(\mathrm{C}_{\mathrm{a}}^{\mathrm{G}}\right)^{2}}{\eta_{1}^{2}+\left(\mathrm{C}_{\mathrm{a}}^{\mathrm{G}}\right)^{2}}\right)\left(\frac{\mathrm{A}_{\mathrm{imm}}^{\mathrm{G}} \mathrm{C}_{\mathrm{p}}^{\mathrm{G}}}{\alpha_{4}+\mathrm{T}_{\mathrm{R}}^{\mathrm{G}}}\right)-\mu_{\mathrm{A}} \mathrm{A}_{\mathrm{mat}}^{\mathrm{G}}-\mathrm{e}_{\mathrm{A}} \mathrm{A}_{\mathrm{mat}}^{\mathrm{G}}$

In Eq. 7, inflammatory APCs are differentiated from $\mathrm{A}_{\mathrm{imm}}^{\mathrm{G}}$ in the presence of $\mathrm{T}_{\mathrm{H}}^{\mathrm{G}}$ and inhibited by $\mathrm{C}_{\mathrm{a}}^{\mathrm{G}}$ and $\mathrm{T}_{\mathrm{R}}^{\mathrm{G}}$ (term 1) $(35,47$, $51,53,54)$ and are assumed to exhibit natural decay (term 2 ).

$$
\frac{\mathrm{dA}_{\mathrm{inf}}^{\mathrm{G}}}{\mathrm{dt}}=\mathrm{a}_{\mathrm{p} 2}\left(1-\frac{\left(\mathrm{C}_{\mathrm{a}}^{\mathrm{G}}\right)^{2}}{\eta_{2}^{2}+\left(\mathrm{C}_{\mathrm{a}}^{\mathrm{G}}\right)^{2}}\right)\left(\frac{\mathrm{A}_{\mathrm{imm}}^{\mathrm{G}} \mathrm{T}_{\mathrm{H}}^{\mathrm{G}}}{\alpha_{5}+\mathrm{T}_{\mathrm{R}}^{\mathrm{G}}}\right)-\mu_{\text {Ainf }} \mathrm{A}_{\mathrm{inf}}^{\mathrm{G}}
$$

The rates of change for $\mathrm{CD} 8^{+}$, regulatory, and $\mathrm{CD} 4^{+} \mathrm{T}$ cells in the graft (Eqs 8, 9, and 10, respectively) depend on the rate at which they enter the graft (term 1), their natural decay (term 2), and their proliferation (term 3). The proliferation of $\mathrm{T}_{\mathrm{E}}^{\mathrm{G}}$ and $\mathrm{T}_{\mathrm{H}}^{\mathrm{G}}$ is inhibited by $C_{a}^{G}(36)$. The parameter $k$ that multiplies the exit rate of $\mathrm{T}$ cells from the lymph node accounts for the fact that not all $\mathrm{T}$ cells exiting the lymph node reach the graft and that $\mathrm{T}$ cells arrive from multiple lymph nodes. The value for $k$ is obtained from the product of the percent of $\mathrm{T}$ cells that reach the graft and the number of lymph nodes from which $\mathrm{T}$ cells originate.

$$
\begin{aligned}
& \frac{\mathrm{dT}_{\mathrm{E}}^{\mathrm{G}}}{\mathrm{dt}}=\mathrm{ke}_{\mathrm{E}} \mathrm{T}_{\mathrm{E}}^{\mathrm{LN}}-\mu_{\mathrm{E}} \mathrm{T}_{\mathrm{E}}^{\mathrm{G}}+\mathrm{r}_{\mathrm{EG}}\left(1-\frac{\left(\mathrm{C}_{\mathrm{a}}^{\mathrm{G}}\right)^{2}}{\eta_{3}^{2}+\left(\mathrm{C}_{\mathrm{a}}^{\mathrm{G}}\right)^{2}}\right) \frac{\mathrm{T}_{\mathrm{E}}^{\mathrm{G}} \mathrm{G}^{\mathrm{G}}}{\beta_{2}+\mathrm{G}^{\mathrm{G}}} \\
& \frac{\mathrm{dT}_{\mathrm{R}}^{\mathrm{G}}}{\mathrm{dt}}=\mathrm{ke}_{\mathrm{R}} \mathrm{T}_{\mathrm{R}}^{\mathrm{LN}}-\mu_{\mathrm{R}} \mathrm{T}_{\mathrm{R}}^{\mathrm{G}}+\frac{\mathrm{r}_{\mathrm{RG}} \mathrm{T}_{\mathrm{R}}^{\mathrm{G}}\left(\mathrm{T}_{\mathrm{E}}^{\mathrm{G}}+\mathrm{T}_{\mathrm{H}}^{\mathrm{G}}\right)}{\alpha_{6}+\mathrm{T}_{\mathrm{R}}^{\mathrm{G}}} \\
& \frac{\mathrm{dT}_{\mathrm{H}}^{\mathrm{G}}}{\mathrm{dt}}=\mathrm{ke}_{\mathrm{H}} \mathrm{T}_{\mathrm{H}}^{\mathrm{LN}}-\mu_{\mathrm{H}} \mathrm{T}_{\mathrm{H}}^{\mathrm{G}}+\mathrm{r}_{\mathrm{HG}}\left(1-\frac{\left(\mathrm{C}_{\mathrm{a}}^{\mathrm{G}}\right)^{2}}{\eta_{4}^{2}+\left(\mathrm{C}_{\mathrm{a}}^{\mathrm{G}}\right)^{2}}\right) \frac{\mathrm{T}_{\mathrm{H}}^{\mathrm{G}} \mathrm{A}_{\mathrm{mat}}^{\mathrm{G}}}{\gamma_{5}+\mathrm{A}_{\mathrm{mat}}^{\mathrm{G}}}
\end{aligned}
$$

Equation 11 describes the dynamics of the mass of the graft. The first and second terms represent the destruction of the graft due to $\mathrm{A}_{\mathrm{inf}}^{\mathrm{G}}$ and $\mathrm{T}_{\mathrm{E}}^{\mathrm{G}}$, respectively. $\mathrm{T}_{\mathrm{R}}^{\mathrm{G}}$ work to inhibit the destruction of the graft through mechanisms that differ from the ones used in the lymph node. It is recognized that in non-lymphoid tissues, $\mathrm{T}_{\mathrm{R}}^{\mathrm{G}}$ do not inhibit the accumulation, nor the proliferation, of $A_{i m m}^{G}$, $\mathrm{T}_{\mathrm{E}}^{\mathrm{G}}$, and $\mathrm{T}_{\mathrm{H}}^{\mathrm{G}}$. Instead, they prevent damage via inhibition of the destructive activities of $A_{\text {inf }}^{G}$ and $T_{E}^{G}$ (in addition to preventing the conversion of $A_{i m m}^{G}$ into $A_{\text {inf }}^{G}$ and $A_{\text {mat }}^{G}$, depicted in Eqs. 6 and 7) (54-56). No growth of graft cells is assumed in this model as stated in our model assumptions.

$$
\frac{\mathrm{dG}^{\mathrm{G}}}{\mathrm{dt}}=-\frac{\mathrm{d}_{\mathrm{inf}} \mathrm{A}_{\mathrm{inf}}^{\mathrm{G}} \mathrm{G}^{\mathrm{G}}}{\left(\alpha_{7}+\mathrm{T}_{\mathrm{R}}^{\mathrm{G}}\right)}-\frac{\mathrm{d}_{\mathrm{E}} \mathrm{T}_{\mathrm{E}}^{\mathrm{G}} \mathrm{G}^{\mathrm{G}}}{\left(\alpha_{8}+\mathrm{T}_{\mathrm{R}}^{\mathrm{G}}\right)}
$$

As defined in Eq. 12, the release of pro-inflammatory cytokines is triggered by the conversion of $\mathrm{A}_{\mathrm{imm}}^{\mathrm{G}}$ into $\mathrm{A}_{\text {mat }}^{\mathrm{G}}$ and $\mathrm{A}_{\text {inf }}^{\mathrm{G}}$ (terms 1 and 4) as well as by the execution of effector functions by both $\mathrm{T}_{\mathrm{E}}^{\mathrm{G}}$ and $\mathrm{T}_{\mathrm{H}}^{\mathrm{G}}$ recognizing their target (10) (terms 2 and 3). The release of $\mathrm{C}_{\mathrm{p}}^{\mathrm{G}}$ by each of these cells is inhibited by $\mathrm{T}_{\mathrm{R}}^{\mathrm{G}}(46,54)$. The natural decay of $\mathrm{C}_{\mathrm{p}}^{\mathrm{G}}$ is modeled in the last term.

$\frac{\mathrm{dC}_{\mathrm{p}}^{\mathrm{G}}}{\mathrm{dt}}=\frac{\rho_{1} \mathrm{~A}_{\mathrm{mat}}^{\mathrm{G}}}{\alpha_{9}+\mathrm{T}_{\mathrm{R}}^{\mathrm{G}}}+\frac{\rho_{2} \mathrm{~T}_{\mathrm{E}}^{\mathrm{G}}}{\alpha_{10}+\mathrm{T}_{\mathrm{R}}^{\mathrm{G}}}+\frac{\rho_{3} \mathrm{~T}_{\mathrm{H}}^{\mathrm{G}}}{\alpha_{11}+\mathrm{T}_{\mathrm{R}}^{\mathrm{G}}}+\frac{\rho_{4} \mathrm{~A}_{\text {inf }}^{\mathrm{G}}}{\alpha_{12}+\mathrm{T}_{\mathrm{R}}^{\mathrm{G}}}-\mu_{\mathrm{C}_{\mathrm{p}}} \mathrm{C}_{\mathrm{p}}^{\mathrm{G}}$

Equation 13 describes the release of $C_{a}^{G}$ due to the conversion of $\mathrm{A}_{\mathrm{imm}}^{\mathrm{G}}$ into $\mathrm{A}_{\text {mat }}^{\mathrm{G}}$ and $\mathrm{A}_{\text {inf }}^{\mathrm{G}}$ - a regulatory pathway embedded in the process of activation to prevent uncontrolled reactivity (35) - and due to activity of $\mathrm{T}_{\mathrm{R}}^{\mathrm{G}}$ (46) that infiltrate the graft (terms 1, 4, and 2 , respectively). Upon encountering pro-inflammatory cytokines, the graft tissue also produces anti-inflammatory mediators (term 3). The last term gives the natural decay of $\mathrm{C}_{a}^{G}$. Since the four populations leading to the production of $\mathrm{C}_{\mathrm{a}}^{\mathrm{G}}$ are already inhibited in the presence of $C_{a}^{G}$, additional inhibition is not included in any of the terms.

$$
\frac{\mathrm{dC}_{\mathrm{a}}^{\mathrm{G}}}{\mathrm{dt}}=\xi_{1} \mathrm{~A}_{\mathrm{mat}}^{\mathrm{G}}+\xi_{2} \mathrm{~T}_{\mathrm{R}}^{\mathrm{G}}+\xi_{3} \mathrm{C}_{\mathrm{p}}^{\mathrm{G}} \mathrm{G}^{\mathrm{G}}+\xi_{4} \mathrm{~A}_{\text {inf }}^{\mathrm{G}}-\mu_{\mathrm{C}_{\mathrm{a}}} \mathrm{C}_{\mathrm{a}}^{\mathrm{G}}
$$




\section{Experimental Data Collection}

Male 8- to 10-week-old Balb/C ( $\left.\mathrm{H}-2^{\mathrm{d}}\right)$, and C57BL/6 (B6; $\left.\mathrm{H}-2^{\mathrm{b}}\right)$ mice were purchased from the Jackson Laboratory (Bar Harbor, ME, USA) and housed in specific pathogen-free facilities at Johns Hopkins University, Baltimore, MD, USA. All experiments were conducted according to Institutional Animal Care and Use Committee-approved protocols.

Heterotopic (intra-abdominal) heart transplantation was performed from BALB/c to B6 mice, as previously described (57). On day 7 post-transplantation, cells from grafts were isolated using an adaptation of the technique described by Setoguchi et al. (58). Briefly, tissues were digested at $37^{\circ} \mathrm{C}$ via 3 consecutive $15-$ min incubations in PBS containing Collagenase IV $(560 \mathrm{U} / \mathrm{ml}$; Worthington) DNAse I (275 U/ml; Amresco), and Dispase II $(0.4 \mathrm{U} / \mathrm{ml}$; Roche). Leukocytes were enriched using a $24 \%$ Histodenz (Sigma-Aldrich)-based gradient separation. These preparations were then used to quantify the content of $\mathrm{CD}^{+}, \mathrm{CD}^{+}$, and Tregs in the rejecting hearts via flow cytometry. Cells were stained using anti-CD $4^{+}$and anti-CD $8^{+} \mathrm{mAb}$ (from BD Bioscience) and anti-Foxp3 $\mathrm{mAb}$ (Affymetrix/eBioscience) according to the manufacturer protocols; samples were acquired using a BD LSR-II flow cytometer. Data were analyzed via FlowJo analysis software (FlowJo, LLC).

Table 4 summarizes the absolute counts and relative ratios of $\mathrm{T}$ cell subsets infiltrating a rejecting heart on post-operative day (POD) 7 deriving from such analysis. From these data, the biological variability observed between animals in the total number of each subset that infiltrate the heart is clearly evident. Strikingly, however, the ratios among $\mathrm{T}$ cell subsets were maintained within very narrow ranges. Consequently, we used the average number of $\mathrm{T}$ cells to set the scale for the number of $\mathrm{T}$ cells in the model, and we optimized various model parameters to the observed ratios of T cells.

A similar approach was used to determine the average number of each $\mathrm{T}$ cell subset in a typical lymph node. Our data agree with a previously published data set (3). Briefly, collection of 16 lymph nodes from multiple animals averaged the identification of $17 \mathrm{e} 6 \mathrm{CD}^{+} \mathrm{T}^{+}$cells, 22e6 $\mathrm{CD}^{+} \mathrm{T}$ cells, and $3 \mathrm{e} 6$ Treg. This renders $1.1 \mathrm{e} 6 \mathrm{CD}^{+} \mathrm{T}$ cells, $1.4 \mathrm{e} 6 \mathrm{CD}^{+} \mathrm{T}$ cells, and $0.19 \mathrm{e} 6$ Treg in the average lymph node. Considering that $\sim 5 \%$ of $\mathrm{T}$ cells are reactive against donor antigens, the average lymph nodes contains (at time 0) 55,000 CD8 ${ }^{+} \mathrm{T}$ cells, 70,000 CD $4^{+} \mathrm{T}$ cells, and 9,500 Treg.

\section{Parameter Estimation}

The model contains 61 parameters. Many of the values of these parameters have been obtained directly from experimental studies

TABLE 4 | Absolute counts and relative ratios of T cell subsets infiltrating a rejecting murine heart on POD 7.

\begin{tabular}{lccccc}
\hline & CD8 & CD4 & $\begin{array}{c}\text { CD8/CD4 } \\
\text { ratio }\end{array}$ & Treg & Treg (\% of CD4) \\
\hline Heart \#1 & $2.7 \mathrm{e} 6$ & $5.4 \mathrm{e} 5$ & 5 & $7.4 \mathrm{e} 4$ & 13.6 \\
Heart \#2 & $4.3 \mathrm{e} 5$ & $8.3 \mathrm{e} 4$ & 5.3 & $1.2 \mathrm{e} 4$ & 14.9 \\
Heart \#3 & $6.5 \mathrm{e} 5$ & $1.8 \mathrm{e} 5$ & 3.7 & $2.5 \mathrm{e} 4$ & 14.1 \\
Average & $\mathbf{1 . 2 7 e 6}$ & $\mathbf{2 . 7 e 5}$ & $\mathbf{4 . 7}$ & $\mathbf{3 . 7 e 4}$ & $\mathbf{1 4 . 2}$ \\
SE & $6 \mathrm{e} 5$ & $1.2 \mathrm{e} 5$ & 0.4 & $1.5 \mathrm{e} 4$ & 0.3
\end{tabular}

$(1-6,8-10,26,32,33,46,47,50-52,57,59-68)$ or other mathematical models of the immune system $(3,23-26,48,69-74)$. Table 3 provides a list of all the model parameter values and sources for their values when possible. A definition of "estimated" in Table 3 indicates that the value was not found directly in the literature but was estimated according to known relationships and ratios among cell populations in the model. For example, due to the potency and cellular similarities of Tregs and helper T cells, the activation rate of $\mathrm{T}_{\mathrm{R}}^{\mathrm{LN}}$ is assumed to be smaller than the activation rate of $\mathrm{T}_{\mathrm{H}}^{\mathrm{LN}}$ (46). As another example, the death rate of $\mathrm{A}_{\mathrm{inf}}^{\mathrm{G}}$ is assumed to equal the death rate of $\mathrm{A}_{\mathrm{mat}}^{\mathrm{G}}$. The constant values for $\mathrm{T}_{\mathrm{EN}}$ and $\mathrm{T}_{\mathrm{HN}}$ are obtained from experiments conducted in the present study (Table 4). According to reported ratios $(26,46,57)$, the $\mathrm{T}_{\mathrm{RN}}$ population should be chosen to be about one-tenth of the helper $\mathrm{T}$ cell initial populations.

Several remaining model parameters are optimized (and are defined as "optimized" in Table 3) to satisfy the following experimental observations:

(1) Presence of all $T$ cells

a. APC conditions $(40,41)$

i. $\mathrm{A}_{\mathrm{mat}}^{\mathrm{G}}$ have a peak population of $\sim 18,000$ cells.

ii. $A_{\mathrm{imm}}^{\mathrm{G}}$ have a peak population of $\sim 12,000$ cells.

iii. $\mathrm{A}_{\mathrm{mat}}^{\mathrm{G}}$ and $\mathrm{A}_{\mathrm{imm}}^{\mathrm{G}}$ peak between days 1 and 3 .

b. Graft destruction (66)

i. A $75 \%$ reduction of the graft mass occurs by 12-14 days following transplantation.

c. $T$ cell ratios (Table 4 and see Experimental Data Collection)

i. The maximum $\mathrm{T}_{\mathrm{E}}^{\mathrm{G}}$ value is approximately five times greater than the maximum $\mathrm{T}_{\mathrm{H}}^{\mathrm{G}}$ value (ratio of average $\mathrm{T}_{\mathrm{E}}^{\mathrm{G}}: \mathrm{T}_{\mathrm{H}}^{\mathrm{G}}$ values is 4.7, Table 4).

ii. The maximum $T_{H}^{G}$ value is approximately seven times greater than the maximum $\mathrm{T}_{\mathrm{R}}^{\mathrm{G}}$ value (ratio of average $\mathrm{T}_{\mathrm{H}}^{\mathrm{G}}: \mathrm{T}_{\mathrm{R}}^{\mathrm{G}}$ values is 7.29 , Table 4).

iii. The maximum number of $\mathrm{T}_{\mathrm{E}}^{\mathrm{LN}}$ occurs at $\sim 4$ days posttransplantation.

iv. The maximum number of $\mathrm{T}_{\mathrm{E}}^{\mathrm{G}}$ occurs at $\sim 6$ days posttransplantation.

(2) Absence of helper T cells $(7,64)$

No graft rejection.

(3) Absence of effector T cells $(7,64)$

Rejection should be delayed slightly.

(4) Absence of all T cells $(40,41)$

a. No damage to the graft.

b. APC measures:

i. Immature APCs: $23000,12000,2100$, and 2000 cells on days $1,3,5$, and 10 .

ii. Mature APCs: $17000,12000,2400,3000$ on days 1, 3, 5, and 10 .

\section{RESULTS}

\section{Model Verification}

The following four model simulations were used to confirm that the model results indeed reflect the assumptions on which the model was built in terms of expected physiological behavior. 


\section{Timing of Graft Rejection}

In the absence of any external manipulation (i.e., administration of immunosuppressive drugs or any immunomodulatory intervention), experimental murine cardiac transplants are rejected at $\sim 12-14$ days after transplantation. Tanaka et al. (66) performed in vivo visualization of murine cardiac allograft rejection and identified the cessation of the heartbeat to occur on day 12 , which corresponded to a $75 \%$ reduction in the measured luminescence of donor tissue from transgenic luciferase-GFP (green fluorescent protein)-modified mice. The present model uses this as an approximate metric, defining graft rejection once the number of graft cells has decreased by $75 \%$ of their initial number. Figure 2A shows the time dynamics of graft rejection predicted by the model. The behavior of other key populations including APCs in the graft, T cells in the lymph node, T cells in the graft, and cytokines in the graft are shown in Figures 2B-F. The number of T cells in the lymph node peaks around days 6-7 in the lymph node and days 7-9 in the graft, which agrees with experimental observations (70). The ratios of $\mathrm{T}_{\mathrm{E}}^{\mathrm{G}}: \mathrm{T}_{\mathrm{H}}^{\mathrm{G}}$ and $\mathrm{T}_{\mathrm{H}}^{\mathrm{G}}: \mathrm{T}_{\mathrm{R}}^{\mathrm{G}}$ at their peaks are calculated to be 4.7 and 7.29 , respectively, in the
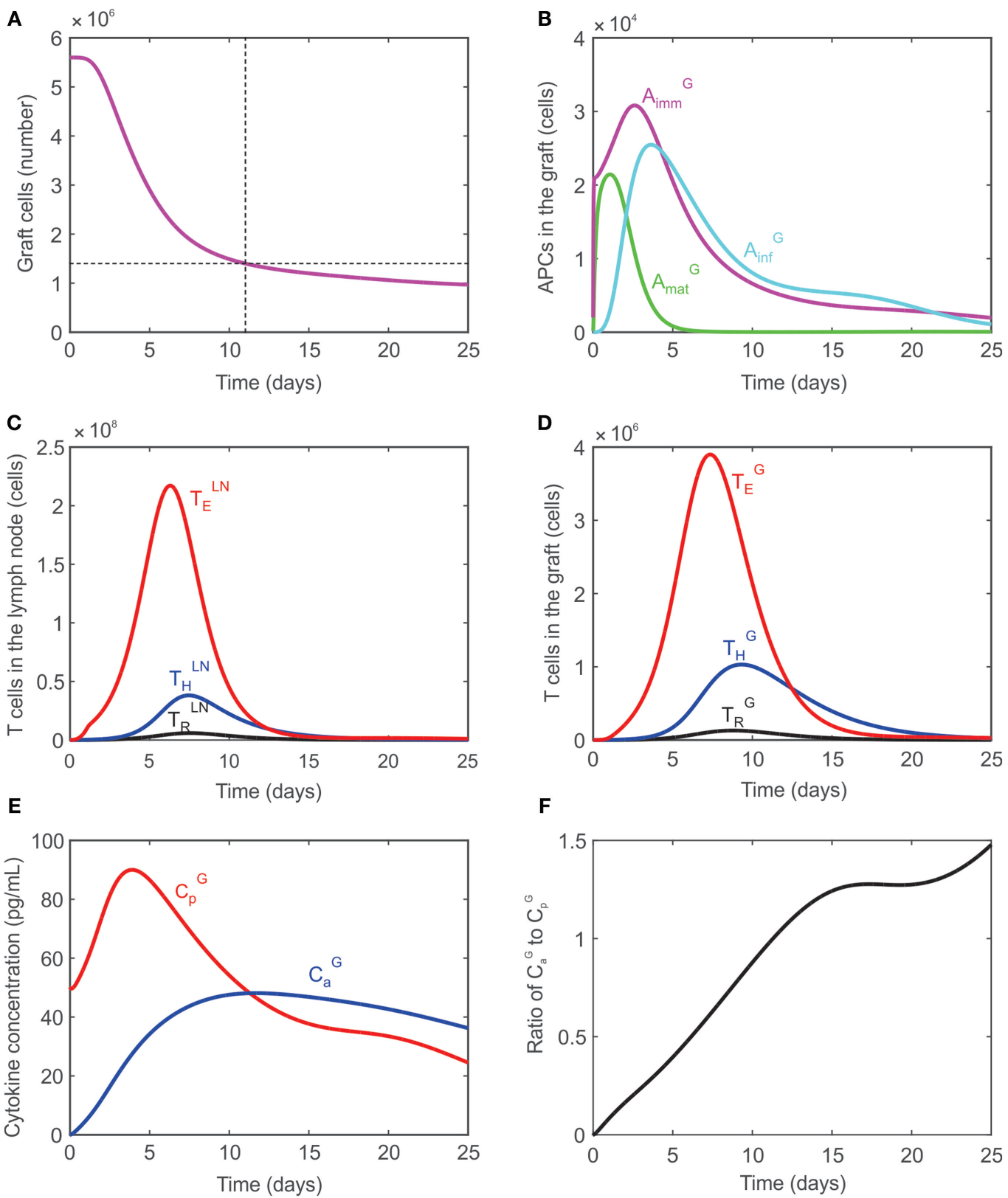

FIGURE 2 | (A) Graft rejection is predicted to occur 11 days following transplantation. (B) Model predicted values of immature APCs ( $A_{\mathrm{imm}}^{\mathrm{G}}$, magenta), mature APCs $\left(A_{\text {mat }}^{G}\right.$, green), and inflammatory APCs ( $A_{\text {inf }}^{G}$, cyan) in the graft. (C) Model predicted values of regulatory $T$ cells (black), $C D 4^{+} T$ cells (blue), $C D 8^{+} T$ cells (red) in the lymph node. (D) Model predicted values of regulatory T cells (black), CD4 ${ }^{+} T$ cells (blue), CD8 ${ }^{+} T$ cells (red) in the graft. (E) Model predicted concentration of pro-inflammatory cytokines $\left(C_{p}^{G}\right.$, red) and anti-inflammatory cytokines $\left(C_{a}^{G}\right.$, blue) in the graft. (F) Ratio of $C_{a}^{G}: C_{p}^{G}$ in the graft. 
graft, which are consistent with experimental values obtained in this study (Table 4).

\section{Graft Rejection in the Absence of $\mathrm{CD}^{+} \mathrm{T}$ Cells $\left(\mathrm{T}_{\mathrm{E}}\right)$}

As demonstrated experimentally (7), transplant rejection can occur even if no $\mathrm{CD}^{+}$cells are present in the system; the time to rejection is just slightly delayed. The absence of $\mathrm{CD}^{+}$cells is simulated in the model by modifying the initial value of naïve effector $\mathrm{T}$ cells to be $\mathrm{T}_{\mathrm{EN}}=0$. As a result, no effector $\mathrm{T}$ cells are generated in the lymph node, but graft rejection is predicted to occur at day 22 (dashed curve, Figure 3A) instead of day 11 when all $\mathrm{T}$ cells are present (solid curve, Figure 3A). Rejection is predicted to occur despite the absence of $\mathrm{CD}^{+} \mathrm{T}$ cells since activated $\mathrm{CD}^{+} \mathrm{T}$ cells in the graft promote the differentiation of inflammatory APCs (Figure 3B) which cause graft destruction. Figure 3C serves to explain why the graft is not destroyed sooner when no $\mathrm{CD}^{+} \mathrm{T}$ cells are present given that $\mathrm{A}_{\mathrm{inf}}^{\mathrm{G}}$ is much higher in their absence (Figure 3B). When all T cells are present, the graft is destroyed by both $\mathrm{A}_{\text {inf }}^{\mathrm{G}}$ and $\mathrm{CD} 8^{+} \mathrm{T}$ cells (terms 1 and 2 in Eq. 11, respectively). The contribution of each of these terms to the rate of change of the graft population is plotted in Figure 3C (solid curves). Specifically, the contribution of the $A_{\text {inf }}^{G}$ term (labeled $\mathrm{d}_{\text {inf }}$ ) is shown in red, the contribution of the CD8 ${ }^{+} \mathrm{T}$ cells when they are present (labeled $\mathrm{d}_{\mathrm{E}}$ ) is shown in black, and the sum of these contributions (labeled total) is shown in blue. The dashed curves correspond to these same cases when $\mathrm{CD}^{+} \mathrm{T}$ cells are absent. Note that in this case the contribution of $\mathrm{A}_{\text {inf }}^{\mathrm{G}}$ (dashed red curve) and the sum of the contributions (dashed blue curve) lie on top of each other since the contribution of the $\mathrm{CD}^{+} \mathrm{T}$ cells is zero (black dashed curve). As can be seen in Figure 3C, the contribution of $\mathrm{A}_{\mathrm{inf}}^{\mathrm{G}}$ when $\mathrm{CD} 8^{+}$T cells are absent exceeds the total solid blue curve until a time point between days 5 and 10 when the blue solid curve exceeds the dashed blue curve. This explains the steep decline in graft population initially in the absence of $\mathrm{T}$ cells followed by a slower decay than when all $\mathrm{T}$ cells are present.

\section{Graft Acceptance in the Absence of All T Cells}

As discussed in Ref. $(10,75)$, animals with no T cells (i.e., no $\mathrm{CD}^{+}$ $\mathrm{T}$ cells, no $\mathrm{CD}^{+} \mathrm{T}$ cells, and no Tregs) are incapable of rejecting transplants. To simulate conditions of no $\mathrm{T}$ cells in the model, the naïve $\mathrm{T}$ cell populations are set to $0: \mathrm{T}_{\mathrm{EN}}=\mathrm{T}_{\mathrm{RN}}=\mathrm{T}_{\mathrm{HN}}=0$. As a result, no $\mathrm{T}$ cells are generated in the lymph node or graft. Although $\mathrm{A}_{\text {mat }}^{\mathrm{G}}$ are activated, the absence of $\mathrm{T}$ cells or $\mathrm{A}_{\text {inf }}^{\mathrm{G}}$ prevents any damage to the graft (Figure 4A), which survives indefinitely. The APC dynamics in the graft under these conditions are compared with data reported by Oberbarnscheidt et al. (40) in Figure 4B. It shows a fairly accurate description of the trend of $A_{\text {mat }}^{G}$ with, however, an overestimation of the accumulation of $\mathrm{A}_{\mathrm{imm}}^{\mathrm{G}}$, a result that we attribute to the model assumptions employed (see Model Limitations). The levels of the pro- and anti-inflammatory cytokines are shown in Figure 4C.

\section{Graft Acceptance in the Absence of $T_{H}$}

Several studies $(7,52,64)$ have demonstrated that the presence of $\mathrm{CD} 4^{+} \mathrm{T}$ cells is a necessary and sufficient condition for rejection.
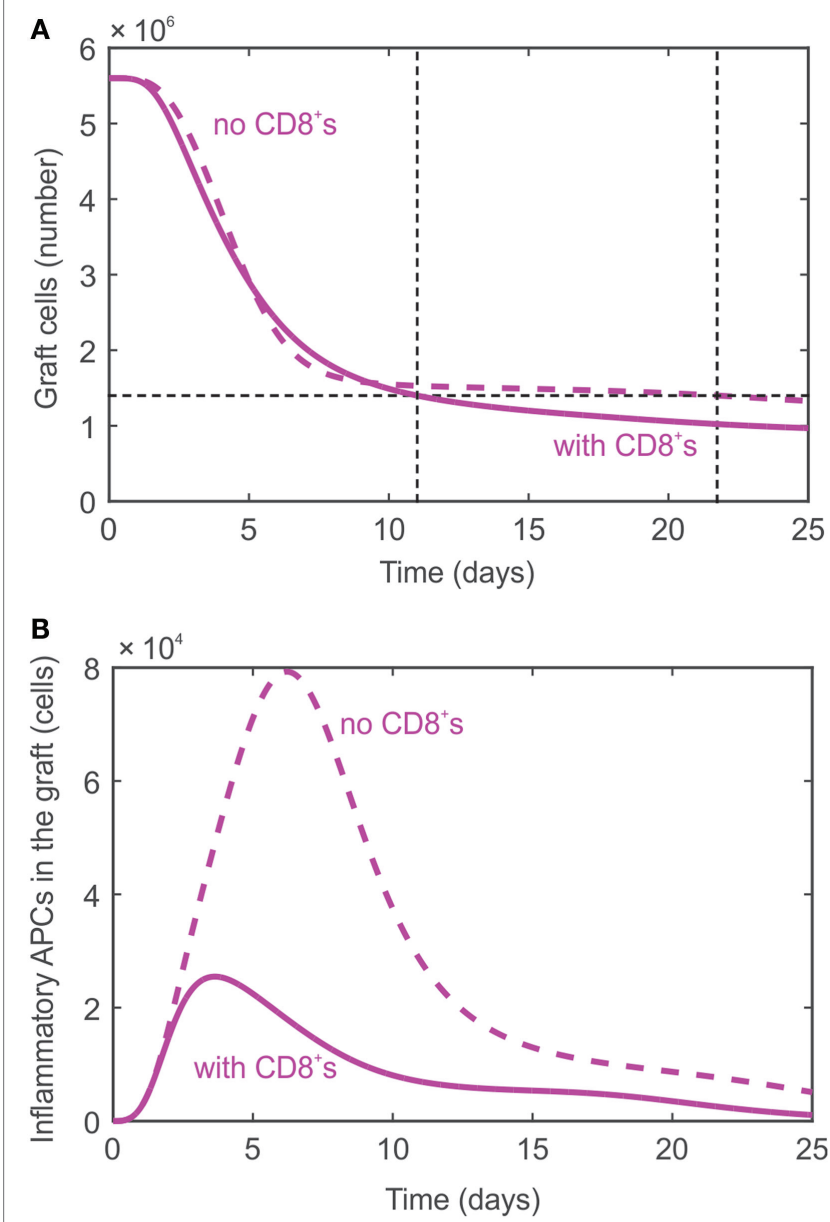

C

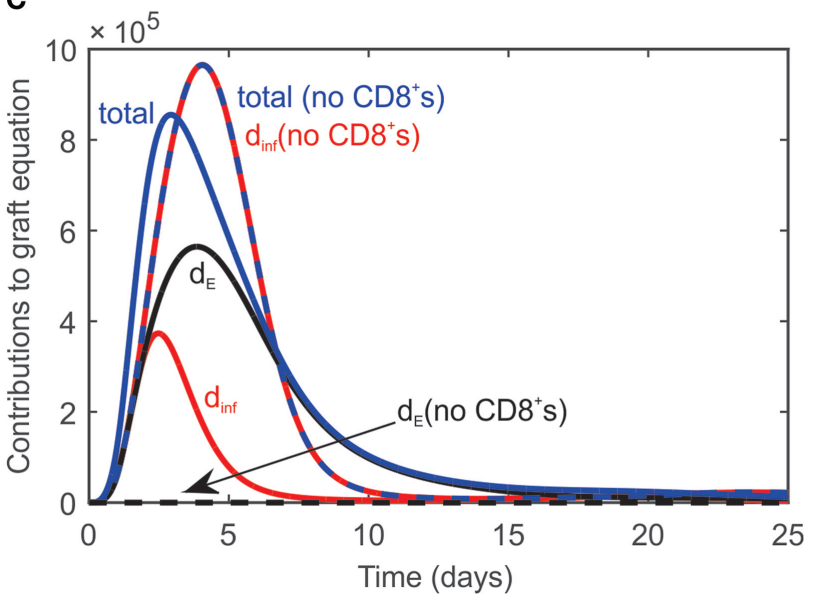

FIGURE 3 | (A) Graft rejection is delayed by $\sim 10$ days in the absence of CD8 ${ }^{+}$ $\mathrm{T}$ cells. Dashed curve: model prediction in the absence of effector T cells. Solid curve: model prediction in the presence of all T cells. (B) Model predicted values of inflammatory APCs in the absence of effector T cells (dashed curve) and in the presence of all T cells (solid curve). (C) Individual contributions of $A_{\text {inf }}^{G}$ (red curve, labeled $d_{\text {inf }}$ ) and $C D 8^{+} T$ cells (black curve, labeled $d_{E}$ ) and combined contribution (blue curve, labeled total) to the rate of change of the graft population in the absence (dashed) and presence (solid) of $\mathrm{CD} 8^{+} \mathrm{T}$ cells. 

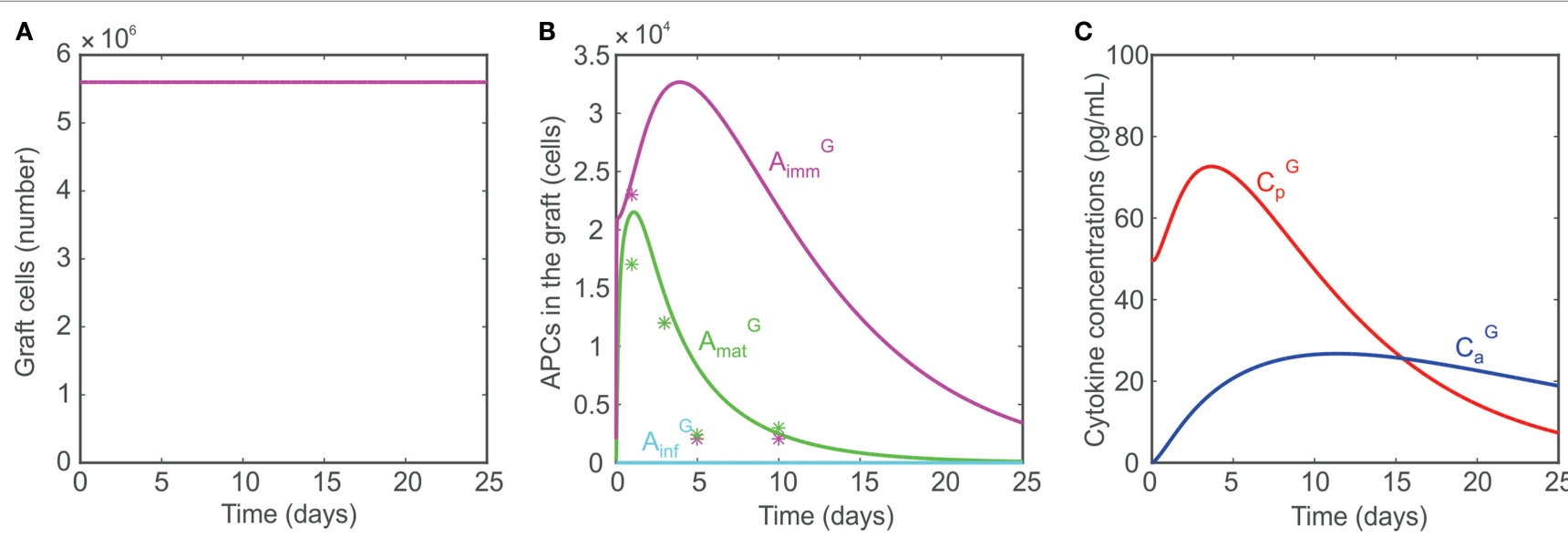

FIGURE 4 | (A) Model predicted number of graft cells when no T cells are present. (B) Model predicted number of mature APCs (green), immature APCs (magenta), and inflammatory APCs (cyan) in the graft when no T cells are present. The model predictions are compared with data reported in Ref. (40, 41) (asterisks).

(C) Concentrations of pro-inflammatory cytokines (red) and anti-inflammatory cytokines (blue) when no T cells are present.

In accordance with this, the model reproduces the finding that in the absence of $\mathrm{CD}^{+} \mathrm{T}$ cells in the lymph node $\left(\mathrm{T}_{\mathrm{HN}}=0\right)$, the graft is accepted since no damage-inducing cells are activated without the contribution of $\mathrm{CD} 4^{+} \mathrm{T}$ cells.

\section{Model Simulations}

The model is used to assess the effect of altering the number of naïve Tregs (adoptive transfer), altering the translocation rate of $\mathrm{T}$ cells from the lymph node to the graft, and performing a transient peri-transplant depletion of $\mathrm{T}$ cells. Insight from simulationgenerated hypotheses may have eventual implications for designing improved therapeutic strategies that promote tolerance of transplants.

\section{Adoptive Transfer of Regulatory T Cells}

Adoptive transfer is a technique by which $\mathrm{T}$ cells are obtained from an animal, stimulated in a polyclonal or antigen-specific fashion, and grown in culture. The cells are then transferred back into the original animal or into a separate animal with the overall goal of expanding the frequency of those T cells. Ultimately, this procedure can be exploited to increase or decrease the reactivity of the immune system. Adoptive transfer has been employed using Treg, aiming to counter graft destruction, and is currently under active investigation for its clinical translation $(67,76)$. The size, frequency, and type of these transfers can vary greatly depending on the system and overall treatment goal. Here, a single injection of naïve Tregs into the lymph node immediately prior to transplantation is simulated by varying $\mathrm{T}_{\mathrm{RN}}$ from 9,500 cells to $3 \mathrm{e} 8$ cells. Figure 5 shows that the graft survival time increases non-linearly with the injection dose. However, fairly rapid transplant rejection is still observed, as expected (67). The model reproduces previous observations that indicate the simple increase of $\mathrm{T}_{\mathrm{RN}}$ would have a very limited impact on transplant survival unless combined with ideal complementary strategies, such as immunosuppression (in a form that does not affect Treg activity, but only effector T cells) and pre-activation of the injected Tregs (to effectively reduce the levels of the other $\mathrm{T}$ cells so that a large ratio of $\mathrm{T}_{\mathrm{R}}$ to $\mathrm{T}$ cells is maintained).

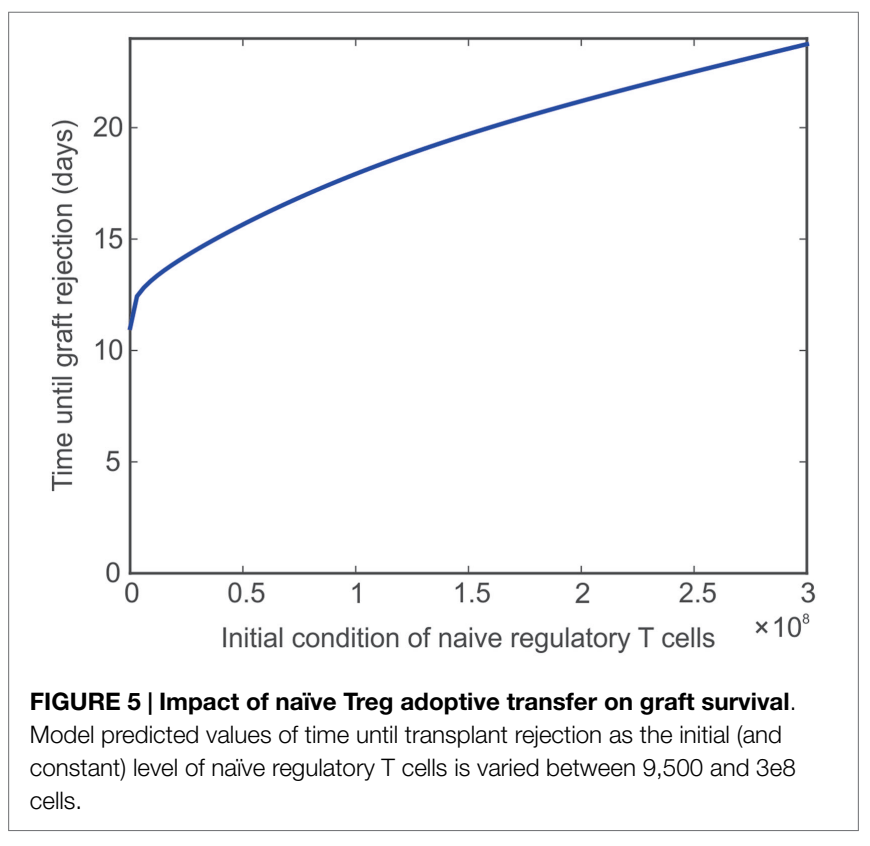

\section{Translocation Rates}

The ease with which $\mathrm{T}$ cells can travel between the lymph node and the graft is expected to influence the destruction of the graft. For example, decreasing the rate $\left(\mathrm{e}_{\mathrm{E}}\right)$ at which $\mathrm{T}_{\mathrm{E}}$ cells translocate from the lymph node to the graft should extend the survival of the graft, though not indefinitely. Figure 6 depicts the effect of $e_{\mathrm{E}}$ alone on graft survival time (i.e., $e_{\mathrm{E}}$ is varied while the other translocation rates are held constant $\mathrm{e}_{\mathrm{H}}=\mathrm{e}_{\mathrm{R}}=0.001 \mathrm{day}^{-1}$, magenta curve) or in combination with the translocation rate of $\mathrm{CD}^{+}$cells (i.e., $\mathrm{e}_{\mathrm{E}}$ and $\mathrm{e}_{\mathrm{H}}$ are varied and assumed equal to each other while $e_{R}=0.001$ day $^{-1}$, blue curve) or with the translocation rate of Tregs (i.e., $e_{E}$ and $e_{H}$ and $e_{R}$ are all varied and assumed equal to each other, black curve). Under normal model conditions, $e_{E}=e_{H}=e_{R}=0.001$ day $^{-1}$. If $e_{E}$ is increased, the graft survival time is decreased from baseline. If both $e_{\mathrm{E}}$ and $e_{H}$ are increased, the graft survival time is even more decreased. 
However, if $e_{E}, e_{H}$, and $e_{R}$ are increased, the survival time is longer because more Tregs are present to inhibit the effects of the $\mathrm{CD}^{+}$and $\mathrm{CD}^{+} \mathrm{T}$ cells. The logic is reversed to the left of $\mathrm{e}_{\mathrm{E}}=0.001 \mathrm{day}^{-1}$.

\section{Delayed Injection of T Cells}

In Figure 7, the model is used to simulate the effect of introducing $\mathrm{T}$ cells into a system that originally has no $\mathrm{T}$ cells for a fixed number of days [simulations for 10 (red), 20 (blue), 30 (black), 40 (magenta), and 50 (green) days are shown]. These simulations were used to assess the ability of the model to reproduce the outcome of published experiments in which $\mathrm{T}$ cells were introduced

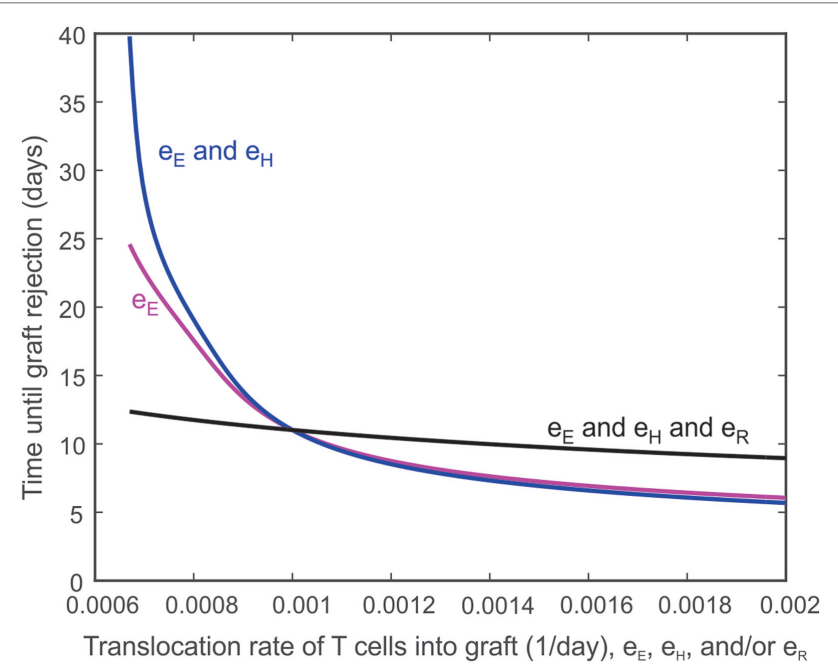

FIGURE 6 | Impact of T cell translocation rates on graft survival. Model predicted values of transplant survival times as the translocation rate of $\mathrm{CD}^{+}$ $T$ cells (i.e., $e_{E}$ is varied while the other translocation rates are held constant $e_{H}=e_{R}=0.001$ day $^{-1}$, magenta curve) is varied alone or in combination with the translocation rate of $\mathrm{CD}^{+}{ }^{+}$cells (i.e., $e_{\mathrm{E}}$ and $\mathrm{e}_{\mathrm{H}}$ are varied and assumed equal to each other while $e_{R}=0.001$ day $^{-1}$, blue curve) or with the translocation of regulatory $T$ cells (i.e., $e_{E}$ and $e_{H}$ and $e_{R}$ are all varied and assumed equal to each other, black curve). into a lymphopenic animal 50 days after heart transplantation. The rationale for this test was that the healing process would make the graft incapable of initiating the rejection response. The reported results, however, refuted that hypothesis and showed a complete rejection initiated even when $\mathrm{T}$ cells were introduced 50 days after transplant (2). The model presented in the current study fails to predict this outcome, but provides valuable insight into the behavior of the system modeled. For example, the red curve in Figure 7A shows that the model predicts graft acceptance when no $\mathrm{T}$ cells are present and graft destruction once $\mathrm{T}$ cells are introduced starting at day 10. As indicated by the additional curves in Figure 7A, the steady state population of graft cells (e.g., the population of graft cells after 200 days) does not change monotonically with the number of days till lymphocyte injection. That is, the steady-state number of graft cells is higher if $\mathrm{T}$ cells are injected at 20 days instead of 10 days, but lower if $\mathrm{T}$ cells are injected at 40 days instead of 10 days. This unexpected behavior is summarized in Figure 7B, which shows the population of graft cells at 200 days as a function of the day at which $\mathrm{T}$ cells are injected. This graph clearly shows the non-monotonic relationship between these values.

\section{DISCUSSION}

In this study, a mathematical model of transplant rejection that encompasses both innate and adaptive elements of the immune response is presented. The model is based on combining experimentally observed ratios of different types of $\mathrm{T}$ cells in the lymph node and graft as well as the time at which their numbers are maximum together with defined characteristics of the immune response that have been reported in the literature $(2-10,26,46,47$, $50,51,57,60,64,66,67,75,77)$. Our efforts in the development of this transplant rejection model were driven by its ultimate application as a tool to provide a better understanding of the complex dynamics that underlie the rejection response and to provide a novel and powerful perspective to predict new methods for preventing graft rejection. Three hypothetical immune interventions are explored in this study: modulation of the frequency of naïve Tregs, alteration of the migration of T cells to the graft, and
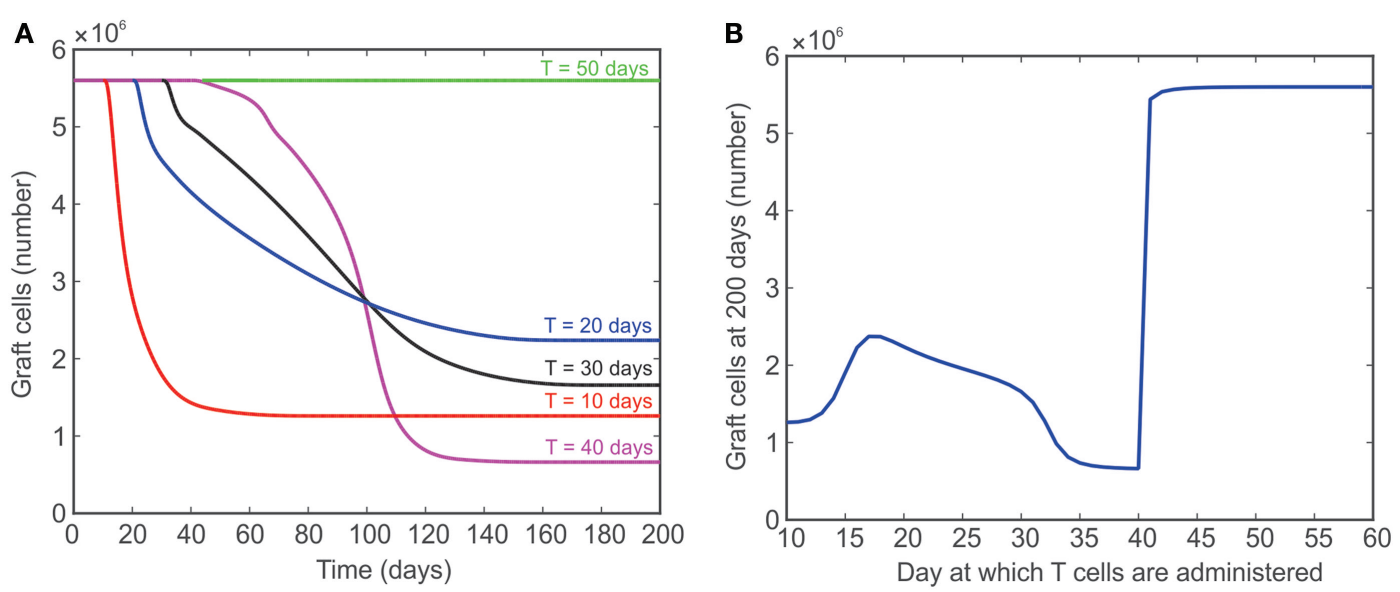

FIGURE 7 | (A) Model predicted number of graft cells when no T cells are initially present and then injected after 10 (red), 20 (blue), 30 (black), 40 (magenta), and 50 (green) days. (B) The number of graft cells predicted by the model at day 200 when $T$ cells are administered at different time points between 10 and 60 days. 
transient depletion of the T cell pool. First, we considered a simple experiment of adoptive transfer of naïve Tregs simulating conditions where the starting number of resting Tregs in the lymph node was altered. Our model indicates that a higher number of Tregs causes an increase in the time to allograft rejection (Figure 5). As expected, however, the impact on graft protection is modest and requires what would be a non-physiological augmentation of Treg numbers to achieve a therapeutic effect. As indicated below, this model is well suited to investigate which combination of strategies could maximize the impact of Treg adoptive transfer (67). For example, although indirectly, the model simulations already suggest a powerful effect of activated Treg migrating to the graft (see comments on third simulation below). While this paper only considers a simple example, the ultimate goal of adoptive transfer is to maintain a high level of Tregs so that they accumulate in both the lymph node and the graft $(46,47,57,67)$. Achieving the greatest possible ratio of Treg to other $\mathrm{T}$ cells would yield the maximum inhibitory effect on the activation of $T_{E}^{G}, T_{H}^{G}, C_{p}^{G}, A_{m a t}^{G}$, and $A_{\text {inf }}^{G}$, and, as a result, provide a significant protection to the graft.

Second, as shown in Figure 6, reducing the translocation rate of $\mathrm{T}_{\mathrm{E}}^{\mathrm{LN}}$ has a non-linear effect on graft destruction. For example, a $50 \%$ decrease in $e_{E}$ yields an $82 \%$ increase in graft survival time, while a $50 \%$ increase in $e_{\mathrm{E}}$ decreases the graft survival time by $34 \%$. Decreasing both the translocation rate of $\mathrm{T}_{\mathrm{E}}^{\mathrm{LN}}$ and the translocation rate of $\mathrm{T}_{\mathrm{H}}^{\mathrm{LN}}$ causes an even more pronounced increase in graft survival time. This protective effect is not only due to a more limited damage inflicted directly by a reduced number of translocating $\mathrm{T}$ cells but is also due to the powerful suppressive effect of Tregs that localize to the graft. In fact, the concomitant reduction of $e_{R}$ with $e_{E}$ and $e_{H}$ shows a much more limited prolongation of graft survival. This behavior helps to explain why the inhibition of $\mathrm{T}_{\mathrm{E}}^{\mathrm{LN}}$ translocation to the graft has a more beneficial effect than their complete absence (Figure 3). This is probably due to the contribution of $\mathrm{T}_{\mathrm{E}}^{\mathrm{LN}}$ to the expansion of Tregs in the lymph node that would then more efficiently control the remaining immune response, a situation that would not occur in the absence of $\mathrm{T}_{\mathrm{E}}^{\mathrm{LN}}$. Thus, the manipulation of activated $\mathrm{T}$ cell migration could have a more profound therapeutic effect than the prevention of their activation or their deletion, as long as the migration of activated Tregs is not concomitantly affected. Such complex dynamics could contribute to understanding the disparate therapeutic effects observed when targeting specific chemokine receptors $(78,79)$. Alternatively, this result highlights the importance of using activated Tregs rather than resting ones for adoptive transfer strategies.

Third, the theoretically predicted non-linear and nonmonotonic relationship between graft survival and the delayed appearance of alloreactive $T$ cells suggests that new experiments to confirm such a relationship are needed to determine if the results suggest a new method for promoting graft survival. The model prediction is in discordance with the experimental observation that the re-introduction of $\mathrm{T}$ cells 50 days post-transplant causes a prompt rejection response (2). This underscores the need to adapt the theoretical model to incorporate other important mechanisms that would contribute to such an outcome. At the same time, this discrepancy indicates that the basic principles implemented in our model are not sufficient to explain the intricate behavior of the immune system and suggest that additional scenarios need to be investigated experimentally. We can speculate two plausible scenarios: (a) the accumulation of pro-inflammatory mediators follows a longer kinetic that supports delayed activation (though not observed experimentally), or (b) the phenomenon of lymphopenia-induced proliferation of $\mathrm{T}$ cells (observed when $\mathrm{T}$ cells are transferred into a lymphopenic mouse) causes the non-specific activation of $\mathrm{T}$ cells that can travel directly to the graft and initiate the rejection response (80). The experimental validation of these possible hypotheses would strengthen the understanding of the non-linear and non-monotonic behavior predicted in this scenario by our model. For example, the model prediction of graft rejection when $\mathrm{T}$ cells are administered at 40 days versus the model prediction of near graft acceptance when $\mathrm{T}$ cells are administered at 42 days warrants additional investigation. This improved understanding would be essential in determining the extent to which the transient elimination of $\mathrm{T}$ cells would be more effective and, possibly, what combinatorial intervention strategy would maximize this effect.

\section{Model Limitations}

Some of the choices and assumptions made in this study limit the capabilities of the model. First, the model focuses on the interactions of T cells, APCs, and inflammatory cytokines, but does not include small-scale details, such as cell signaling or the secretion of various factors. Additionally, cytokines are grouped into two categories (pro- and anti-inflammatory signals) and are tracked only in the graft, not in the lymph node. Considering the vast number of individual cytokine molecules involved in a full immune response as well as their independent dynamics, the relative strength of their effects on the overall immune system (as well as independent effects on individual cell types), and their unique production and decay rates, a model that accounts for each cytokine molecule individually will rapidly become complicated and cumbersome. But, studies show that the overall balance of these signals and their specific varieties can significantly impact graft outcome $(4,6,33,47)$. Effects of pro- and anti-inflammatory cytokines are assumed to be included in parameters such as $r_{E}, r_{R}$, and $r_{H}$. The tradeoff of specificity for simplicity allows the model to reproduce general behavior.

Some of the diversity and antigen-specificity of the various cell populations are generally neglected in the model. B cells and memory $\mathrm{T}$ cells are excluded, allowing the model to be compared with experimental preparations only involving a naïve $\mathrm{T}$ cell repertoire $(6,7,9,50,64,77,81)$. One aspect of initiation of acute organ rejection includes cross-reactivity of non-naïve $\mathrm{T}$ cells cross-reacting against specific foreign MHC molecules (HLA in humans) presented by graft cells. The contributions of non-naïve $\mathrm{T}$ cells can vary widely, depending on the immunological history of the individual (including the formation of heterologous immunity toward the transplant), and serve as a point of customization that can be adjusted in subsequent iterations of this model. The model also does not accurately represent the accumulation of immature APC in the graft when no T cells are present in the system. This limitation likely derives from the 
simplification of incorporating multiple APC types into one variable and having $\mathrm{A}_{\mathrm{inf}}^{\mathrm{G}}$ and $\mathrm{A}_{\text {mat }}^{\mathrm{G}}$ originating from the same starting population. Moreover, the effects of mechanisms of tolerization, namely the induction of T cell anergy by immature APC or the conversion of $\mathrm{T}$ cells into Tregs, are not presently included but could be incorporated in the future. These processes contribute significantly to the underlying anti-inflammatory processes, as they allow $\mathrm{A}_{\mathrm{imm}}^{\mathrm{G}}$ and $\mathrm{T}_{\mathrm{R}}^{\mathrm{G}}$ to inhibit activated cells in ways currently not being modeled. Modeling these factors may require probabilistic considerations of co-stimulatory encounters of antigen with or without pro-inflammatory signals. Additionally, graft rejection experiments typically conclude upon rejection and no further measurements of the graft mass are taken. Thus, any model predictions post-rejection unfortunately cannot be compared to available experimental observations.

The model also assumes that the entire graft is attacked at day 0 . In reality, due to the three-dimensional heterogeneity of the system, sites undergoing an inflammatory response are damaged more. There are also early and late inflammatory populations that could be included in the model using a time delay. This would require converting the system into delay differential equations, as in (25).

\section{Model Extensions}

Excitingly, despite the presented limitations, multiple avenues of experimentation to understand the rejection response and to assess the efficacy of therapeutic interventions are suggested by the results obtained with this model. For example, the current model predicts that altering the $\mathrm{T}_{\mathrm{RN}}$ population has a significant impact on graft survival, as shown in Figures 5 and 6. The size, timing, and repetition of Treg transfers can vary widely; many experiments have started to identify appropriate combinations for maximizing graft life $(10,46,47,51,57,67,77)$. This model can be used to simulate a multitude of adoptive transfer regimens that may or may not have been explored experimentally. In addition, pharmaceutical immunosuppression can be simulated by targeting terms in the equations that represent chemical pathways. In particular, there is much interest in directly manipulating pro- and anti-inflammatory signals as novel immunosuppressive strategies; model simulation could help to identify optimal regimens. The model can also be used to assess the compatibility between

\section{REFERENCES}

1. Caplan AL. Organ transplants: the costs of success. Hastings Cent Rep (1983) 13(6):23-32. doi:10.2307/3560741

2. Bingaman AW, Ha J, Waitze SY, Durham MM, Cho HR, Tucker-Burden C, et al. Vigorous allograft rejection in the absence of danger. J Immunol (2000) 164(6):3065-71. doi:10.4049/jimmunol.164.6.3065

3. Catron DM, Itano AA, Pape KA, Mueller DL, Jenkins MK. Visualizing the first $50 \mathrm{hr}$ of the primary immune response to a soluble antigen. Immunity (2004) 21(3):341-7. doi:10.1016/j.immuni.2004.08.007

4. Dai Z, Lakkis FG. The role of cytokines, CTLA-4 and costimulation in transplant tolerance and rejection. Curr Opin Immunol (1999) 11(5):504-8. doi:10. 1016/S0952-7915(99)00008-4

5. He G, Hart J, Kim OS, Szot GL, Siegel CT, Thistlethwaite JR, et al. The role of CD8 and CD4 $\mathrm{T}$ cells in intestinal allograft rejection: a comparison the current strategy of immunosuppression and experimental immune interventions and guide the identification of optimal conversion strategies. Moreover, future iterations of the model could encompass the heterogeneity of reactivity of each individual repertoire of alloreactive $\mathrm{T}$ cells (combined with the extent of mismatch in HLA molecules between donor and recipient) to achieve a more "personalized" level of intervention - an ideal goal of current medical research. Overall, the model can be used to hypothesize that pathways are viable targets for pharmaceutical intervention based on parameter sensitivity analysis and model dynamics. Combined with a continuous cycle of suggested experimentation and model optimization, this approach has potential for valuable contributions in the quest of transplant tolerance induction.

\section{AUTHOR CONTRIBUTIONS}

JA, AM, AA, BO, GB, and GR contributed to the theoretical elaboration of the computational model described herein; JA and AM wrote the model script; JA, AM, and AA performed model simulations; $\mathrm{BO}, \mathrm{GB}$, and GR executed all wet-lab experiments; JA, $\mathrm{AM}, \mathrm{AA}, \mathrm{BO}, \mathrm{GB}$, and GR wrote the manuscript while providing critical feedback.

\section{ACKNOWLEDGMENTS}

We thank Dr. Yoram Vodovotz, Dr. James Faeder, and Ms. Joyeeta Dutta-Moscato for invaluable feedback in the initial elaboration of the theoretical model of transplant rejection. We also thank Xiaoling Zhang of the Ross Research Flow Cytometry Core (Johns Hopkins University) for invaluable assistance with all flow cytometry-based experiments.

\section{FUNDING}

This work was supported by a Burroughs Wellcome Fund BWF 1014050 Collaborative Research Travel Grant (to JA), the IUPUI School of Science Institute for Mathematical Modeling and Computational Science Grant to Enhance Interdisciplinary Research and Education (iM2CS-GEIRE) award (to JA), a National Institutes of Health grant number UL1TR000005 in the form of a CTSI-PEIR (to GR), and grant number R21HL127355 (to GR).

of monoclonal antibody-treated and knockout mice. Transplantation (1999) 67(1):131-7. doi:10.1097/00007890-199901150-00022

6. Heeger PS. T-cell allorecognition and transplant rejection: a summary and update. Am J Transplant (2003) 3(5):525-33. doi:10.1034/j.1600-6143.2003. 00123.x

7. Krieger NR, Yin DP, Fathman CG. CD4+ but not CD8+ cells are essential for allorejection. J Exp Med (1996) 184(5):2013-8. doi:10.1084/ jem.184.5.2013

8. Linderman JJ, Riggs T, Pande M, Miller M, Marino S, Kirschner DE. Characterizing the dynamics of CD4+ T cell priming within a lymph node. J Immunol (2010) 184(6):2873-85. doi:10.4049/jimmunol.0903117

9. van Maurik Av, Herber M, Wood KJ, Jones ND. Cutting edge: CD4+CD25+ alloantigen-specific immunoregulatory cells that can prevent CD8+ T cellmediated graft rejection: implications for anti-CD154 immunotherapy. J Immunol (2002) 169(10):5401-4. doi:10.4049/jimmunol.169.10.5401 
10. Wood KJ, Goto R. Mechanisms of rejection: current perspectives. Transplantation (2012) 93(1):1-10. doi:10.1097/TP.0b013e31823cab44

11. Turka LA, Linsley PS, Lin H, Brady W, Leiden JM, Wei RQ, et al. T-cell activation by the CD28 ligand B7 is required for cardiac allograft rejection in vivo. Proc Natl Acad Sci U S A (1992) 89:11102-5. doi:10.1073/pnas.89.22. 11102

12. Pearson TC, Alexander DZ, Corbascio M, Hendrix R, Ritchie SC, Linsley PS, et al. Analysis of the B7 costimulatory pathway in allograft rejection. Transplantation (1997) 63(10):1463-9. doi:10.1097/00007890-199705270-00016

13. Pearson TC, Alexander DZ, Winn KJ, Linsley PS, Lowry RP, Larsen CP. Transplantation tolerance induced by CTLA4-Ig. Transplantation (1994) 57(12):1701-6. doi:10.1097/00007890-199457120-00002

14. Sayegh MH, Akalin E, Hancock WW, Russell ME, Carpenter CB, Linsley PS, et al. CD28-B7 blockade after alloantigenic challenge in vivo inhibits Th1 cytokines but spares Th2. J Exp Med (1995) 181(5):1869-74. doi:10.1084/jem. 181.5.1869

15. Lenschow DJ, Zeng Y, Thistlethwaite JR, Montag A, Brady W, Gibson MG, et al. Long-term survival of xenogeneic pancreatic islet grafts induced by CTLA4Ig. Science (1992) 257:789-92. doi:10.1126/science.1323143

16. Kirk AD, Harlan DM, Armstrong NN, Davis TA, Dong Y, Gray GS, et al. CTLA4-Ig and anti-CD40L prevent renal allograft rejection in primates. Proc Natl Acad Sci U S A (1997) 94:8789-94. doi:10.1073/pnas.94.16.8789

17. Levisetti MG, Padrid PA, Szot GL, Mittal N, Meehan SM, Wardrip CL, et al. Immunosuppressive effects of human CTLA4Ig in a non-human primate model of allogeneic pancreatic islet transplantation. J Immunol (1997) 159(11):5187-91.

18. Adams AB, Shirasugi N, Jones TR, Durham MM, Strobert EA, Cowan S, et al. Development of a chimeric anti-CD40 monoclonal antibody that synergizes with LEA29Y to prolong islet allograft survival. J Immunol (2005) 174(1):542-50. doi:10.4049/jimmunol.174.1.542

19. Vincenti F, Dritselis A, Kirkpatrick P. Belatacept. Nat Rev Drug Discov (2011) 10(9):655-6. doi:10.1038/nrd3536

20. Riella LV, Sayegh MH. T-cell co-stimulatory blockade in transplantation: two steps forward one step back! Expert Opin Biol Ther (2013) 13(11):1557-68. doi:10.1517/14712598.2013.845661

21. Sachs DH, Sykes M, Kawai T, Cosimi AB. Immuno-intervention for the induction of transplantation tolerance through mixed chimerism. Semin Immunol (2011) 23(3):165-73. doi:10.1016/j.smim.2011.07.001

22. Leventhal J, Abecassis M, Miller J, Gallon L, Tollerud D, Elliott MJ, et al. Tolerance induction in HLA disparate living donor kidney transplantation by donor stem cell infusion: durable chimerism predicts outcome. Transplantation (2013) 95(1):169-76. doi:10.1097/TP.0b013e3182782fc1

23. Kim PS, Levy D, Lee PP. Modeling and simulation of the immune system as a self-regulating network. Methods Enzymol (2009) 467:79-109. doi:10.1016/ S0076-6879(09)67004-X

24. Kim PS, Lee PP, Levy D. Modeling regulation mechanisms in the immune system. J Theor Biol (2007) 246(1):33-69. doi:10.1016/j.jtbi.2006.12.012

25. Lee HY, Topham DJ, Park SY, Hollenbaugh J, Treanor J, Mosmann TR, et al. Simulation and prediction of the adaptive immune response to influenza $A$ virus infection. J Virol (2009) 83(14):7151-65. doi:10.1128/JVI.00098-09

26. Caridade M, Graca L, Ribeiro RM. Mechanisms underlying CD4+ Treg immune regulation in the adult: from experiments to models. Front Immunol (2013) 4:378. doi:10.3389/fimmu.2013.00378

27. An G. Introduction of a framework for dynamic knowledge representation of the control structure of transplant immunology: employing the power of abstraction with a solid organ transplant agent-based model. Front Immunol (2015) 6:561. doi:10.3389/fimmu.2015.00561

28. Day JD, Metes DM, Vodovotz Y. Mathematical modeling of early cellular innate and adaptive immune responses to ischemia/reperfusion injury and solid organ allotransplantation. Front Immunol (2015) 6:484. doi:10.3389/fimmu. 2015.00484

29. Chong AS, Alegre ML, Miller ML, Fairchild RL. Lessons and limits of mouse models. Cold Spring Harb Perspect Med (2013) 3(12):a015495. doi:10.1101/ cshperspect.a015495

30. Suchin EJ, Langmuir PB, Palmer E, Sayegh MH, Wells AD, Turka LA. Quantifying the frequency of alloreactive $\mathrm{T}$ cells in vivo: new answers to an old question. J Immunol (2001) 166(2):973-81. doi:10.4049/jimmunol.166.2.973

31. Chong AS, Alegre ML. The impact of infection and tissue damage in solid-organ transplantation. Nat Rev Immunol (2012) 12(6):459-71. doi:10.1038/nri3215
32. He H, Stone JR, Perkins DL. Analysis of robust innate immune response after transplantation in the absence of adaptive immunity. Transplantation (2002) 73(6):853-61. doi:10.1097/00007890-200203270-00005

33. Liang Y, Christopher K, Finn PW, Colson YL, Perkins DL. Graft produced interleukin- 6 functions as a danger signal and promotes rejection after transplantation. Transplantation (2007) 84(6):771-7. doi:10.1097/01.tp.0000281384. 24333.0b

34. Moore KW, de Waal Malefyt R, Coffman RL, O'Garra A. Interleukin-10 and the interleukin-10 receptor. Annu Rev Immunol (2001) 19:683-765. doi:10.1146/ annurev.immunol.19.1.683

35. Murray PJ, Smale ST. Restraint of inflammatory signaling by interdependent strata of negative regulatory pathways. Nat Immunol (2012) 13(10):916-24. doi:10.1038/ni.2391

36. Sabat R, Grütz G, Warszawska K, Kirsch S, Witte E, Wolk K, et al. Biology of interleukin-10. Cytokine Growth Factor Rev (2010) 21(5):331-44. doi:10.1016/j. cytogfr.2010.09.002

37. Malliaras K, Zhang Y, Seinfeld J, Galang G, Tseliou E, Cheng K, et al. Cardiomyocyte proliferation and progenitor cell recruitment underlie therapeutic regeneration after myocardial infarction in the adult mouse heart. EMBO Mol Med (2013) 5(2):191-209. doi:10.1002/emmm.201201737

38. Doevendans PA, Daemen MJ, de Muinck ED, Smits JF. Cardiovascular phenotyping in mice. Cardiovasc Res (1998) 39(1):34-49. doi:10.1016/S0008-6363(98) 00073-X

39. Tirziu D, Giordano FJ, Simons M. Cell communications in the heart. Circulation (2010) 122(9):928-37. doi:10.1161/CIRCULATIONAHA.108.847731

40. Oberbarnscheidt MH, Zeng Q, Li Q, Dai H, Williams AL, Shlomchik WD, et al. Non-self recognition by monocytes initiates allograft rejection. J Clin Invest (2014) 124(8):3579-89. doi:10.1172/JCI74370

41. Su CA, Iida S, Abe T, Fairchild RL. Endogenous memory CD8 T cells directly mediate cardiac allograft rejection. Am J Transplant (2014) 14(3):568-79. doi 10.1111/ajt.12605

42. Mori DN, Kreisel D, Fullerton JN, Gilroy DW, Goldstein DR. Inflammatory triggers of acute rejection of organ allografts. Immunol Rev (2014) 258(1):132-44. doi:10.1111/imr.12146

43. Walsh PT, Strom TB, Turka LA. Routes to transplant tolerance versus rejection; the role of cytokines. Immunity (2004) 20(2):121-31. doi:10.1016/S10747613(04)00024-X

44. O'Gorman WE, Dooms H, Thorne SH, Kuswanto WF, Simonds EF, Krutzik PO, et al. The initial phase of an immune response functions to activate regulatory T cells. J Immunol (2009) 183(1):332-9. doi:10.4049/jimmunol.0900691

45. Wood KJ, Bushell A, Hester J. Regulatory immune cells in transplantation. Nat Rev Immunol (2012) 12(6):417-30. doi:10.1038/nri3227

46. Wood KJ, Sakaguchi S. Regulatory T cells in transplantation tolerance. Nat Rev Immunol (2003) 3(3):199-210. doi:10.1038/nri1027

47. Zhang N, Schröppel B, Lal G, Jakubzick C, Mao X, Chen D, et al. Regulatory $\mathrm{T}$ cells sequentially migrate from inflamed tissues to draining lymph nodes to suppress the alloimmune response. Immunity (2009) 30(3):458-69. doi:10.1016/j.immuni.2008.12.022

48. Day J, Rubin J, Vodovotz Y, Chow CC, Reynolds A, Clermont G. A reduced mathematical model of the acute inflammatory response II. Capturing scenarios of repeated endotoxin administration. J Theor Biol (2006) 242(1):237-56. doi: 10.1016/j.jtbi.2006.02.015

49. Kronik N, Kogan Y, Elishmereni M, Halevi-Tobias K, Vuk-Pavlović S, Agur Z. Predicting outcomes of prostate cancer immunotherapy by personalized mathematical models. PLoS One (2010) 5(12):e15482. doi:10.1371/journal. pone. 0015482

50. De Boer RJ, Homann D, Perelson AS. Different dynamics of CD4+ and CD8+ T cell responses during and after acute lymphocytic choriomeningitis virus infection. J Immunol (2003) 171(8):3928-35. doi:10.4049/jimmunol.171. 8.3928

51. Joffre $\mathrm{O}$, Santolaria $\mathrm{T}$, Calise $\mathrm{D}, \mathrm{Al}$ Saati $\mathrm{T}$, Hudrisier $\mathrm{D}$, Romagnoli $\mathrm{P}$, et al. Prevention of acute and chronic allograft rejection with CD4+CD25+Foxp3+ regulatory T lymphocytes. Nat Med (2008) 14(1):88-92. doi:10.1038/nm1688

52. Filatenkov AA, Jacovetty EL, Fischer UB, Curtsinger JM, Mescher MF, Ingulli E. CD4 T cell-dependent conditioning of dendritic cells to produce IL-12 results in CD8-mediated graft rejection and avoidance of tolerance. J Immunol (2005) 174(11):6909-17. doi:10.4049/jimmunol.174.11.6909

53. Sakaguchi S, Yamaguchi T, Nomura T, Ono M. Regulatory T cells and immune tolerance. Cell (2008) 133(5):775-87. doi:10.1016/j.cell.2008.05.009 
54. Vignali DA, Collison LW, Workman CJ. How regulatory T cells work. Nat Rev Immunol (2008) 8(7):523-32. doi:10.1038/nri2343

55. Gratz IK, Campbell DJ. Organ-specific and memory Treg cells: specificity, development, function, and maintenance. Front Immunol (2014) 5:333. doi:10.3389/fimmu.2014.00333

56. Shevach EM. Mechanisms of foxp3+ T regulatory cell-mediated suppression. Immunity (2009) 30(5):636-45. doi:10.1016/j.immuni.2009.04.010

57. Raimondi G, Sumpter TL, Matta BM, Pillai M, Corbitt N, Vodovotz Y, et al. Mammalian target of rapamycin inhibition and alloantigen-specific regulatory $\mathrm{T}$ cells synergize to promote long-term graft survival in immunocompetent recipients. J Immunol (2010) 184(2):624-36. doi:10.4049/jimmunol.0900936

58. Setoguchi K, Schenk AD, Ishii D, Hattori Y, Baldwin WM III, Tanabe K, et al. LFA-1 antagonism inhibits early infiltration of endogenous memory CD8 T cells into cardiac allografts and donor-reactive T cell priming. Am J Transplant (2011) 11(5):923-35. doi:10.1111/j.1600-6143.2011.03492.x

59. Brandwood A, Noble KR, Schindhelm K. Phagocytosis of carbon particles by macrophages in vitro. Biomaterials (1992) 13(9):646-8. doi:10.1016/01429612(92)90035-M

60. Chalasani G, Li Q, Konieczny BT, Smith-Diggs L, Wrobel B, Dai Z, et al. The allograft defines the type of rejection (acute versus chronic) in the face of an established effector immune response. J Immunol (2004) 172(12):7813-20. doi:10.4049/jimmunol.172.12.7813

61. Fu H, Kishore M, Gittens B, Wang G, Coe D, Komarowska I, et al. Selfrecognition of the endothelium enables regulatory $\mathrm{T}$-cell trafficking and defines the kinetics of immune regulation. Nat Commun (2014) 5:3436. doi:10.1038/ ncomms 4436

62. Giannoudis PV, Harwood PJ, Loughenbury P, Van Griensven M, Krettek C, Pape HC. Correlation between IL-6 levels and the systemic inflammatory response score: can an IL-6 cutoff predict a SIRS state? J Trauma (2008) 65(3):646-52. doi:10.1097/TA.0b013e3181820d48

63. Krieger NR, Fathman CG. The use of CD4 and CD8 knockout mice to study the role of T-cell subsets in allotransplant rejection. J Heart Lung Transplant (1997) 16(3):263-7.

64. Pietra BA, Wiseman A, Bolwerk A, Rizeq M, Gill RG. CD4 T cell-mediated cardiac allograft rejection requires donor but not host MHC class II. J Clin Invest (2000) 106(8):1003-10. doi:10.1172/JCI10467

65. Regoes RR, Barber DL, Ahmed R, Antia R. Estimation of the rate of killing by cytotoxic T lymphocytes in vivo. Proc Natl Acad Sci U S A (2007) 104(5):1599-603. doi:10.1073/pnas.0508830104

66. Tanaka M, Swijnenburg RJ, Gunawan F, Cao YA, Yang Y, Caffarelli AD, et al. In vivo visualization of cardiac allograft rejection and trafficking passenger leukocytes using bioluminescence imaging. Circulation (2005) 112(9 Suppl):I105-10. doi:10.1161/CIRCULATIONAHA.104.524777

67. Tang Q, Lee K. Regulatory T-cell therapy for transplantation: how many cells do we need? Curr Opin Organ Transplant (2012) 17(4):349-54. doi:10.1097/MOT. 0b013e328355a992

68. Turnquist HR, Raimondi G, Zahorchak AF, Fischer RT, Wang Z, Thomson AW. Rapamycin-conditioned dendritic cells are poor stimulators of allogeneic CD4+ $\mathrm{T}$ cells, but enrich for antigen-specific Foxp $3+\mathrm{T}$ regulatory cells and promote organ transplant tolerance. J Immunol (2007) 178(11):7018-31. doi:10.4049/ jimmunol.178.11.7018
69. Arciero JC, Ermentrout GB, Upperman JS, Vodovotz Y, Rubin JE. Using a mathematical model to analyze the role of probiotics and inflammation in necrotizing enterocolitis. PLoS One (2010) 5(4):e10066. doi:10.1371/journal. pone. 0010066

70. Kirschner DE, Chang ST, Riggs TW, Perry N, Linderman JJ. Toward a multiscale model of antigen presentation in immunity. Immunol Rev (2007) 216:93-118. doi:10.1111/j.1600-065X.2007.00490.x

71. León K, Carneiro J, Peréz R, Montero E, Lage A. Natural and induced tolerance in an immune network model. J Theor Biol (1998) 193(3):519-34. doi:10.1006/ jtbi. 1998.0720

72. León K, Peréz R, Lage A, Carneiro J. Modelling T-cell-mediated suppression dependent on interactions in multicellular conjugates. J Theor Biol (2000) 207(2):231-54. doi:10.1006/jtbi.2000.2169

73. Regoes RR, Yates A, Antia R. Mathematical models of cytotoxic T-lymphocyte killing. Immunol Cell Biol (2007) 85(4):274-9. doi:10.1038/sj.icb.7100053

74. Reynolds A, Rubin J, Clermont G, Day J, Vodovotz Y, Ermentrout GB. A reduced mathematical model of the acute inflammatory response: I. Derivation of model and analysis of anti-inflammation. J Theor Biol (2006) 242(1):220-36. doi:10.1016/j.jtbi.2006.02.016

75. Zecher D, Li Q, Williams AL, Walters JT, Baddoura FK, Chalasani G, et al. Innate immunity alone is not sufficient for chronic rejection but predisposes healed allografts to T cell-mediated pathology. Transpl Immunol (2012) 26(2-3):113-8. doi:10.1016/j.trim.2011.12.006

76. van der Net JB, Bushell A, Wood KJ, Harden PN. Regulatory T cells: first steps of clinical application in solid organ transplantation. Transpl Int (2016) 29(1):3-11. doi:10.1111/tri.12608

77. Wang J, Zhang L, Tang J, Jiang S, Wang X. Adoptive transfer of transplantation tolerance mediated by $\mathrm{CD} 4+\mathrm{CD} 25+$ and $\mathrm{CD} 8+\mathrm{CD} 28$ - regulatory $\mathrm{T}$ cells induced by anti-donor-specific T-cell vaccination. Transplant Proc (2008) 40(5):1612-7. doi:10.1016/j.transproceed.2008.02.079

78. Hancock WW. Chemokine receptor-dependent alloresponses. Immunol Rev (2003) 196:37-50. doi:10.1046/j.1600-065X.2003.00084.x

79. Hancock WW, Wang L, Ye Q, Han R, Lee I. Chemokines and their receptors as markers of allograft rejection and targets for immunosuppression. Curr Opin Immunol (2003) 15(5):479-86. doi:10.1016/S0952-7915(03)00103-1

80. Tchao NK, Turka LA. Lymphodepletion and homeostatic proliferation: implications for transplantation. Am J Transplant (2012) 12(5):1079-90. doi:10.1111/ j.1600-6143.2012.04008.x

81. Vu MD, Amanullah F, Li Y, Demirci G, Sayegh MH, Li XC. Different costimulatory and growth factor requirements for CD4+ and CD8+ T cell-mediated rejection. J Immunol (2004) 173(1):214-21. doi:10.4049/jimmunol.173.1.214

Conflict of Interest Statement: The authors declare that the research was conducted in the absence of any commercial or financial relationships that could be construed as a potential conflict of interest.

Copyright $\odot 2016$ Arciero, Maturo, Arun, Oh, Brandacher and Raimondi. This is an open-access article distributed under the terms of the Creative Commons Attribution License (CC BY). The use, distribution or reproduction in other forums is permitted, provided the original author(s) or licensor are credited and that the original publication in this journal is cited, in accordance with accepted academic practice. No use, distribution or reproduction is permitted which does not comply with these terms. 